\title{
Continental-wide distribution of crayfish species in Europe: update and maps
}

\author{
A. Kouba ${ }^{(1), \star}$, A. Petrusek ${ }^{(2)}$, P. Kozák ${ }^{(1)}$ \\ Received December 15, 2013 \\ Revised February 13, 2014 \\ Accepted February 14, 2014
}

Key-words:

crayfish

distribution,

indigenous

species, invasive species, native range, maps

\section{ABSTRACT}

Recently published astacological studies substantially improved available data on distribution of crayfish in various European regions. At the same time, spread of invasive species has been recorded, additional nonindigenous species became established in various countries, and losses of populations of native species due to crayfish plague and other negative factors were observed. We overview recent advances in this knowledge, and provide updated colour maps of the distribution of all crayfish species present in Europe. These maps are originally based on the data from the Atlas of Crayfish in Europe published in 2006 as a result of the CRAYNET project, and were further updated from more recently published reports, grey literature, and especially thanks to contributions and feedback of over 70 specialists from 32 countries. Separate maps are available for all indigenous crayfish species in Europe as well as for three most widespread non-indigenous crayfish species. Additionally, two maps give locations of known findings of crayfish species introduced to Europe after 1980. These newly established alien species have so far restricted distributions; however, the frequency of recent reports suggests that findings of such species resulting from releases of aquarium pets will further increase.

RÉSUMÉ

Répartition à l'échelle continentale des espèces d'écrevisses en Europe : mises à jour et cartes

Mots-clés : distribution des écrevisses, espèces indigènes, espèces envahissantes,
Les études astacologiques récemment publiées ont sensiblement amélioré les données disponibles sur la distribution des écrevisses dans les différentes régions européennes. Dans le même temps, la propagation des espèces envahissantes a été enregistrée, des espèces non indigènes supplémentaires se sont établies dans différents pays, et des pertes de populations d'espèces indigènes en raison de la peste des écrevisses et d'autres facteurs négatifs ont été observées. Nous synthétisons les progrès récents dans la connaissance, et fournissons des cartes en couleur mises à jour de la distribution de toutes les espèces d'écrevisses présentes en Europe. Ces cartes sont à l'origine basées sur les données de l'Atlas des écrevisses en Europe publié en 2006 à la suite du projet CRAYNET, et ont ensuite été mises à jour à partir des études publiées plus récemment, de la

(1) Faculty of Fisheries and Protection of Waters, South Bohemian Research Center of Aquaculture and Biodiversity of Hydrocenoses, University of South Bohemia in České Budějovice, Zátiší 728/II, 38925 Vodñany, Czech Republic

(2) Department of Ecology, Faculty of Science, Charles University in Prague, Viničná 7, 12844 Prague 2, Czech Republic

* Corresponding author: akouba@frov.jcu.cz 
aire de répartition naturelle, cartes littérature grise, et en particulier grâce à des contributions et des commentaires de plus de 70 spécialistes de 32 pays. Des cartes distinctes sont disponibles pour toutes les espèces d'écrevisses indigènes en Europe ainsi que pour trois espèces d'écrevisses non indigènes les plus répandues. En outre, deux cartes donnent l'emplacement des signalements connus d'espèces d'écrevisses introduites en Europe après 1980. Ces espèces étrangères nouvellement établies ont jusqu'ici des distributions limitées. Cependant, la fréquence des rapports récents suggèrent que les signalements de ces espèces, résultant de rejets d'animaux d'aquarium, vont encore augmenter.

\section{INTRODUCTION}

Freshwater crayfish (Crustacea, Decapoda, Astacida) are often considered keystone species in freshwater habitats (Momot, 1995; Dorn and Wojdak, 2004) or ecosystem engineers (Creed and Reed, 2004; Edwards et al., 2009), due to their prominent impact on physical structure of the environment as well as on biological interactions. As such, loss of crayfish populations, colonization of naturally crayfish-free habitats, or replacement of ecologically contrasting crayfish species may substantially impair local biodiversity and ecosystem services. Many factors have affected the distribution of crayfish in Europe in the past. These included active introductions of crayfish suitable for consumption by humans, as well as various negative anthropogenic impacts such as water pollution and habitat modifications (Holdich, 2002; Füreder et al., 2006; Holdich et al., 2009). The most prominent factor, however, was the 19th century accidental introduction of crayfish plague, a disease caused by the oomycete Aphanomyces astaci, which had a devastating impact on native crayfish species across the continent (Alderman, 1996; Edgerton et al., 2004). The spread of non-indigenous crayfish species (NICS) of North American origin in the 20th century has also irreversibly influenced the patterns of crayfish distribution in Europe (Holdich et al., 2009). At present, situation in many regions seems dynamic, with losses of native populations due to disease outbreaks (e.g., Bohman et al., 2006; Kozubíková et al., 2008) as well as other negative factors, and new records of alien crayfish that colonize new areas through waterways or due to humanmediated introductions (Souty-Grosset et al., 2006). This results not only in changes of distributions of various species but also in findings of taxa previously not known from European open waters.

Data overviewing and highlighting such changes may be of high importance for astacologists, freshwater ecologists, conservationists as well as invasion biologists. Losses of native crayfish populations as well as occurrence and spread of alien species have been often documented and predicted at the level of particular rivers and their tributaries (e.g., Ellis et al., 2012; Aklehnovich and Razlutskij, 2013; Sousa et al., 2013), administrative units (e.g., Groß et al., 2008; Boets et al., 2012) or countries (e.g., Trožić-Borovac, 2011; Pursiainen and Mattila, 2012; Simić et al., 2008). Distributions summarized at continental scale are, however, less frequent and vary in details (Holdich, 2002; Füreder, 2009). Nevertheless, maps showing the overall distribution of species are sought after by the astacological community, as they are useful for general overviews of species status as well as for presentation purposes.

After decades of scattered information sources, the publication of the excellent "Atlas of Crayfish in Europe" (Souty-Grosset et al., 2006; further referred to as "Atlas") represented a major advance in providing summary information about the diversity, ecology, distribution, and conservation of crayfish in Europe. The Atlas was one of the key results of the CRAYNET project (a thematic network "European crayfish as keystone species - linking science, management and economics with sustainable environmental quality", financed from the Fifth RTD Framework Programme of the European Union), which brought together a substantial proportion of European researchers involved in studying various aspects of crayfish biology. The maps 
presenting crayfish occurrence in areas defined by the Common European Chorological Grid Reference System (CGRS, i.e., approx. $50 \times 50 \mathrm{~km}$ grid), a part of the "Species Files" chapter of the Atlas (Holdich et al., 2006), summarized the data obtained by CRAYNET contributing partners. The original ranges of European native species (based on expert assessment) were also provided in the maps. However, due to uneven geographic distribution of research efforts and participation in CRAYNET activities, the quality of the available data varied among regions. In particular, the data was substantially lacking for many east European countries. Advances in astacological research since the publication of the Atlas allowed filling at least some of these gaps (e.g., Maguire et al., 2011; Trožić-Borovac, 2011; Simić et al., 2008), and also led to re-assessment of species identity and diversity of some of the alien species present in European waters (e.g., Chucholl and Daudey, 2008; Filipová et al., 2011). Furthermore, expansion of invasive species was well documented for some regions e.g., Italy (Aquiloni et al., 2010) and Romania (Pârvulescu et al., 2009, 2012), and isolated populations of various recently introduced alien species were discovered in many European countries (e.g., Scalici et al., 2009; Jaklič and Vrezec, 2011; Chucholl et al., 2012).

Some of these changes that became known since the publication of the Atlas were reflected in the comprehensive review by Holdich et al. (2009), which nevertheless re-used the original 2006 maps. Thus no updated maps that would summarize the distribution of crayfish in Europe have been available until recently. When writing our Czech monograph entitled "Biology and Culture of Crayfish" (Kozák et al., 2013), we attempted to fill this gap by compiling distribution maps with all information available to us until October 2012. The demand for well accessible maps with accompanying text in English available to wide astacological community led us to updating the maps further, and providing this review that incorporates most recent data (up to January 2014).

\section{MATERIALS AND METHODS}

We extracted distributions from maps published in the Species files chapter of the "Atlas of Crayfish in Europe" (Holdich et al., 2006) for all European indigenous crayfish species (ICS: Astacus spp. and Austropotamobius spp.) and widespread non-indigenous crayfish species introduced to Europe before the 1980s (Old NICS: Orconectes limosus, Pacifastacus leniuscuIus, and Procambarus clarkii). The distributions were re-plotted on a new colour map suitable for presentation purposes, which highlights altitudinal variation of European landscape. For all ICS, we included the estimates of original native ranges of the species based on Holdich et al. (2006) but occasionally modified according to available distributional and phylogeographic reports and recommendations of contributors from the respective countries. Additionally, we prepared two maps summarizing information on non-indigenous crayfish species that still have restricted distributions in Europe, which were introduced after 1980 (New NICS). One map was prepared jointly for Cherax spp. and Orconectes spp., and another for Procambarus spp. Distribution data from Holdich et al. (2006) were further updated from several sources. We used information from recently published scientific papers that could not be reflected in the Atlas, as well from as the grey literature (theses, reports, etc.). However, a major part of the update could only be achieved thanks to contributions and feedback of 74 biologists (mainly astacologists) from altogether 32 countries (see their complete list in Acknowledgements). Information obtained from these sources was reflected by adding or removing the dots indicating the presence of a particular crayfish species in the respective cell of the Common European Chorological Grid Reference System (usually an area of approx. $50 \times 50 \mathrm{~km}$ ). We further summarized in a table and summed up the presence of each species in countries and/or geographic territories in Europe and adjacent regions. For comparative purposes, we used the same list of territories as Holdich et al. (2009), who provided data separately for parts of the United Kingdom, Kaliningrad region (a geographically separate region belonging to Russia), large islands in the Mediterranean and Atlantic Ocean (belonging to Italy, Spain, Portugal, and France, respectively), and included also some Western Asian countries with established crayfish populations (Armenia, Azerbaijan, Georgia, and Kazakhstan). 
With the exception of Astacus leptodactylus, in which we indicated in the map a widespread presence in European Russia by hatching (even without information about specific localities), we aimed to maintain the resolution of the maps at the same level as in Holdich et al. (2006). Thus, some information available to us could not be appropriately reflected in the presented maps. For example, data for most of France, where extensive spread of alien crayfish has been documented (Collas et al., 2007), are available only as presence/absence in particular departments, at much rougher scale than the CGRS grid used by us. Thus, although we obtained some information for eastern part of the country (M. Collas, pers. comm.) and additional locations for some of the species could be extracted from published sources (e.g., Filipová et al., 2013), we are aware that the distribution of alien crayfish in this country is underrepresented. This is, however, true for many other regions as well, as the quality of the maps matches the quality of information and resolution available for different countries.

When creating the maps, we tried to reflect as accurately as possible all pieces of information and feedback obtained. However, given the continental scale of the resulting maps and potential minor inaccuracies caused by fitting the CGRS grid over the background map, the result should be considered as an approximate summary of the present knowledge on crayfish distribution in Europe, rather than an authoritative source for any single dot.

\section{RESULTS AND DISCUSSION}

\section{> INDIGENOUS CRAYFISH SPECIES}

There are contrasting views on diversity of indigenous European crayfish species, ranging from a conservative recognition of two genera (Astacus, Austropotamobius) and five species (a classification reflected in Holdich et al. 2006, 2009), to over-splitting of Eastern European crayfish, with additional two genera and numerous species (Starobogatov, 1995). Thanks to recent molecular analyses, it has been recognised that both Austropotamobius spp. may represent species complexes. It may be assumed that although many crayfish taxa described in Eastern Europe likely represent only local forms or ecomorphs, validity of some as distinct species will be confirmed in the future. Until a consensus is reached, however, we follow the conservative view, and the presumed species complexes are treated together.

\section{>ASTACUS ASTACUS (LINNAEUS, 1758); NOBLE CRAYFISH (FIGURE 1)}

Despite its relatively vast range in Europe, the noble crayfish is taxonomically homogeneous, and it status as a single species is well accepted. Its phylogeography revealing evidence for multiple refugia has been recently documented by Schrimpf et al. (2013b), and while substantial haplotype diversity was documented in particular in the western Balkans, there was no evidence for any cryptic lineages within the species.

Number of territories $(n=39)$ inhabited by the noble crayfish (Table I) has not changed since Holdich et al. (2009). Some eastern and southeastern European countries had been, however, substantially underrepresented at that time. As data from regions such as Romania (Pârvulescu and Zaharia, 2014), Russia, and Ukraine became more available, confirmed presence could be substantially widened. Some minor changes (confirmation of species presence) based on ongoing astacological research can be seen across other parts of its range as well (e.g., Groß et al., 2008; Simić et al., 2008; Trožić-Borovac, 2011). The presence of noble crayfish in the Lefkara dam, Cyprus (Stephanou, 1987) is also indicated.

Although confirmations on species disappearance at regional scales are always more difficult to prove and, to some degree, depend on survey effort, substantial distribution losses have been reported from Belarus and Lithuania. In the Netherlands, only a single population remains (but a reintroduction program to increase the number of occupied sites has recently started; Ottburg and Roessing, 2012), and the species became completely extinct in Flanders, Belgium (Boets et al., 2012). Further losses may be expected in some European 


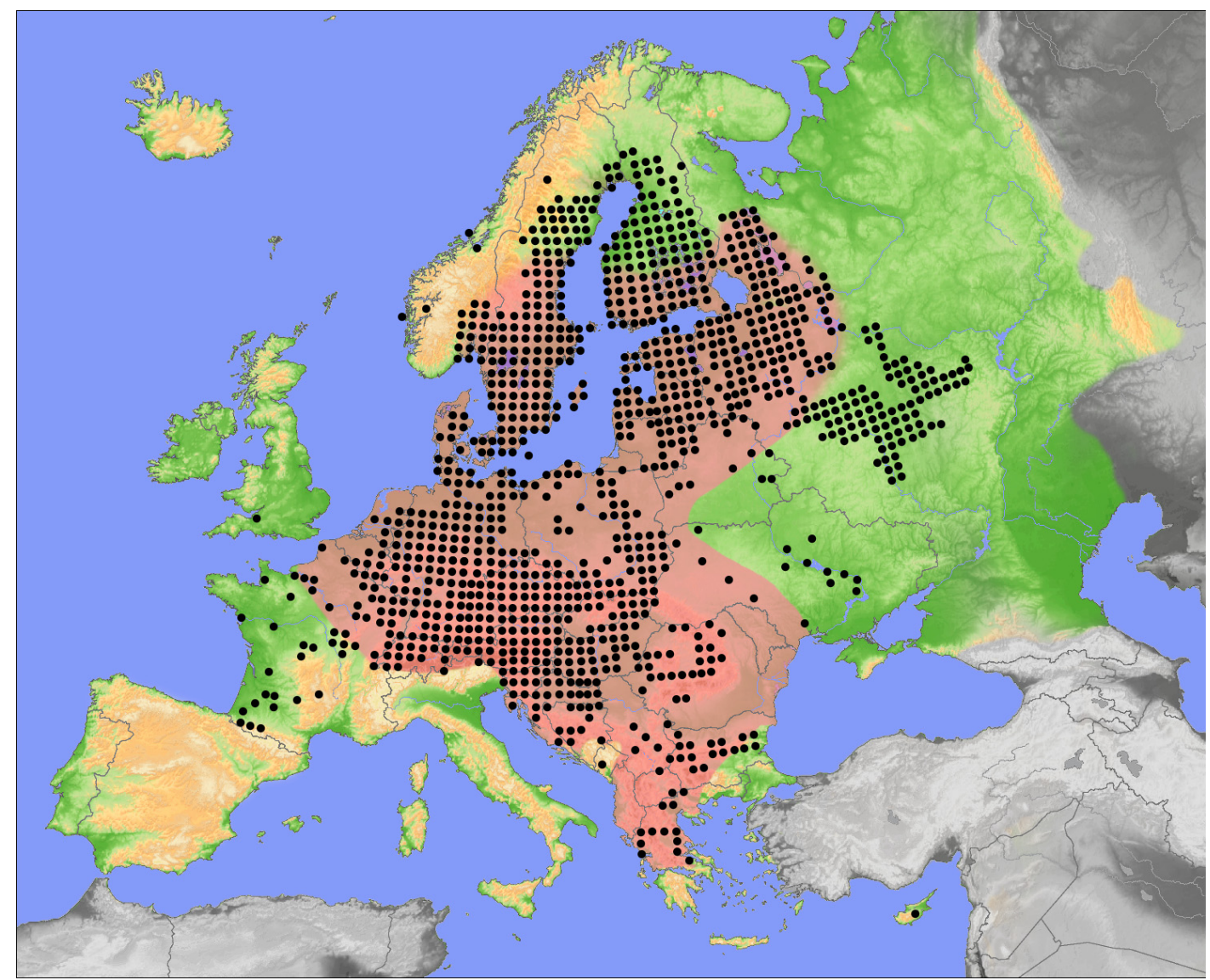

Figure 1

Distribution of Astacus astacus (noble crayfish) in Europe. Presumed native range is highlighted.

countries even at the applied $50 \times 50 \mathrm{~km}$ grid scale if negative pressures on noble crayfish populations, particularly from alien species, persist.

Besides updating the present distribution of the species, we also restricted the estimate of its native range in Scandinavia and Northwestern Russia, based on the feedback from M. Pursiainen and M. Schletterer.

\section{> ASTACUS LEPTODACTYLUS SENSU LATO; NARROW-CLAWED CRAYFISH (FIGURE 2)}

The systematic and nomenclatural status of narrow-clawed crayfish remains in state of flux. The astacological community from Western and Central Europe usually refers to a single species $A$. leptodactylus, although it became widely accepted that this taxon probably represents a species complex (Holdich et al., 2006, 2009). The assumption stems from morphology-based concept applied by Eastern European astacologists, who often separate narrow-clawed crayfish (sensu lato) from $A$. astacus into a genus Pontastacus comprising different number of species (Starobogatov, 1995; Śmietana et al., 2006). Further studies on morphometric, meristic (Maguire and Dakić, 2011), cytologic (Kostyuk et al., 2013) and molecular aspects (Maguire et al., 2014) may in the near future reconcile the differing views on A. leptodactylus. Until this issue gets resolved by application of modern integrative taxonomic approaches, we find it most convenient to present in the maps the distribution of the narrow-clawed crayfish in a wide sense. 


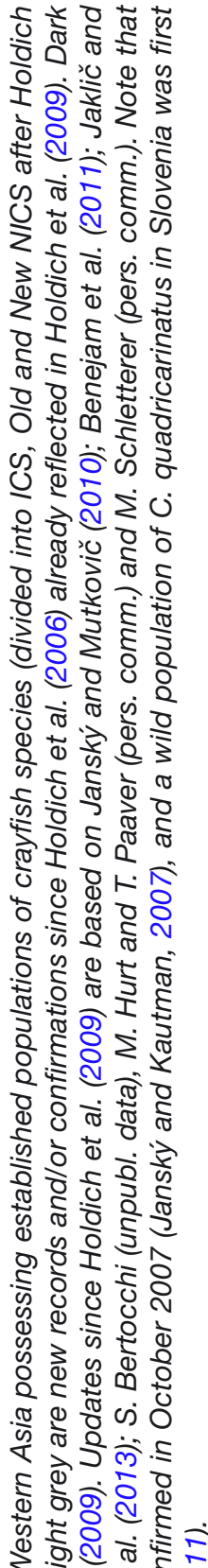

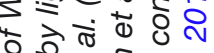

की

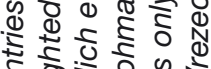

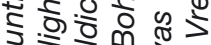

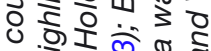

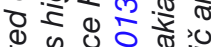
茛. के के के के

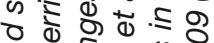
สิ

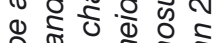
О 万灭

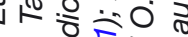

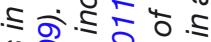
ฯ $0 \cong$ - 吾 o : : 0

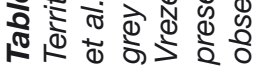

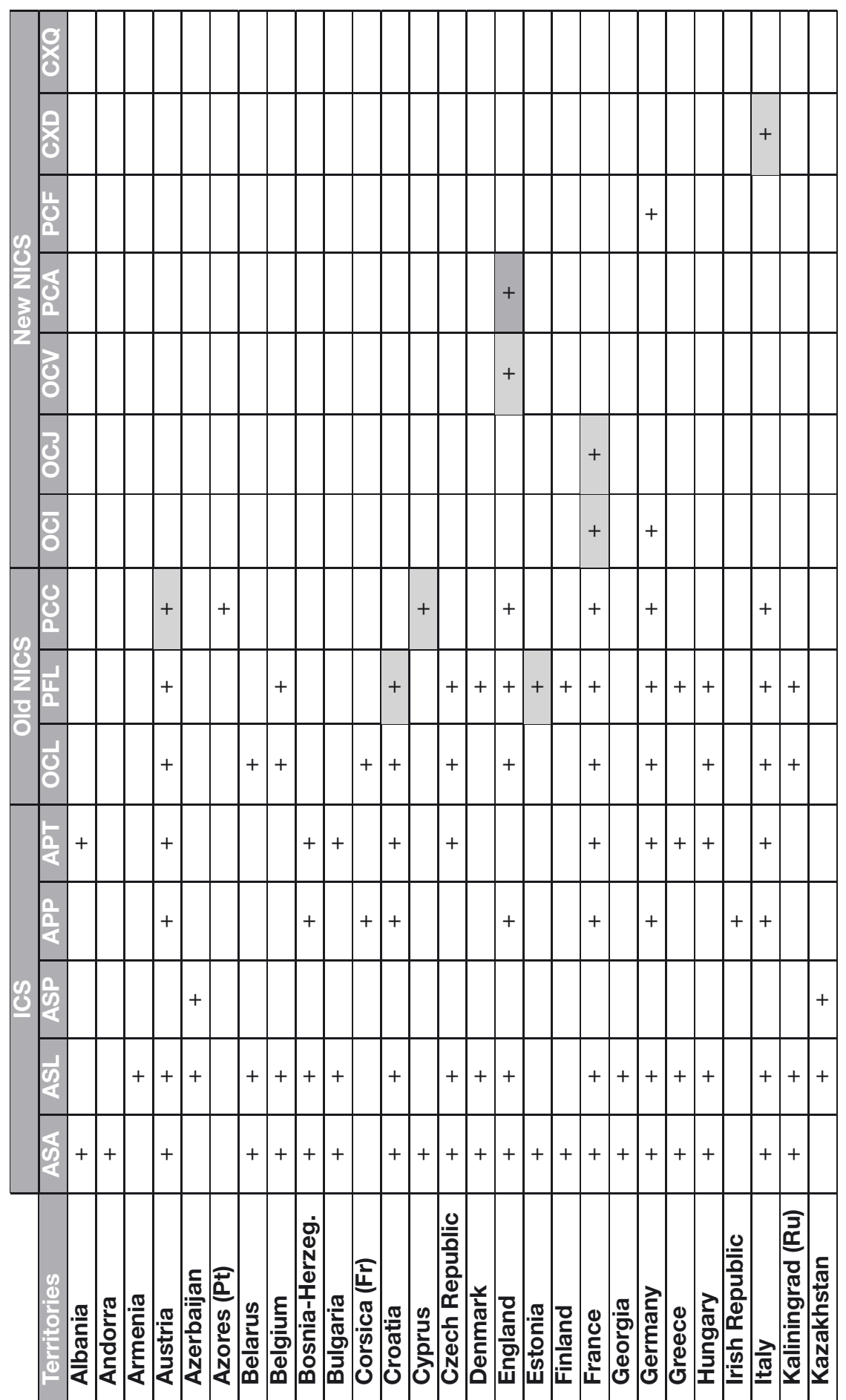




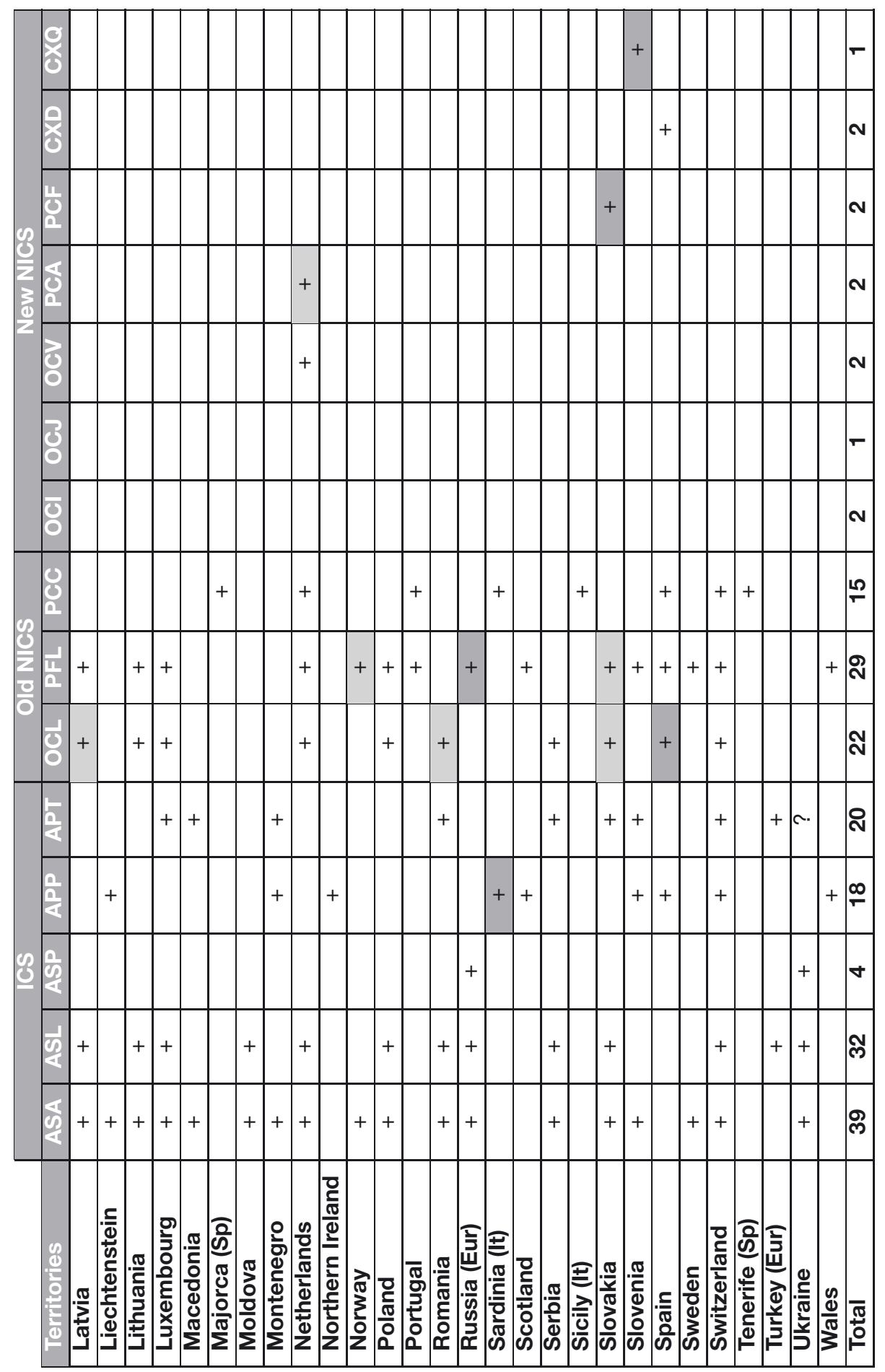

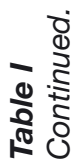

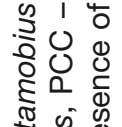

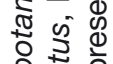

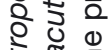

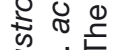

उर

$1 \frac{5}{5} \underset{2}{2}$

웅

$=\pi$

is

कर

옹

वृ

인

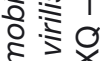

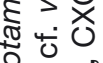

$\therefore$ \&

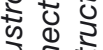

रे ठ

100

满 $1 \frac{9}{1}$

$<>\frac{1}{0}$

50

잉

है क्ष

0 ह क

S

\&

安过.

1 ठे ब

के ठ?

$<1$ 过

जं

s

तो 1

용. 咅茴

क

ब $\frac{8}{\pi}$

วิ ญ 홍

क्ष

年安 世-

1 宁莃

४०

की $\frac{5}{\sqrt{5}}$

कह हो छ

कब के

ช 11

क्ष

1 o

पำ 음

का 1 离.

iூ

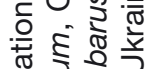

,

ब웡

裹影影 


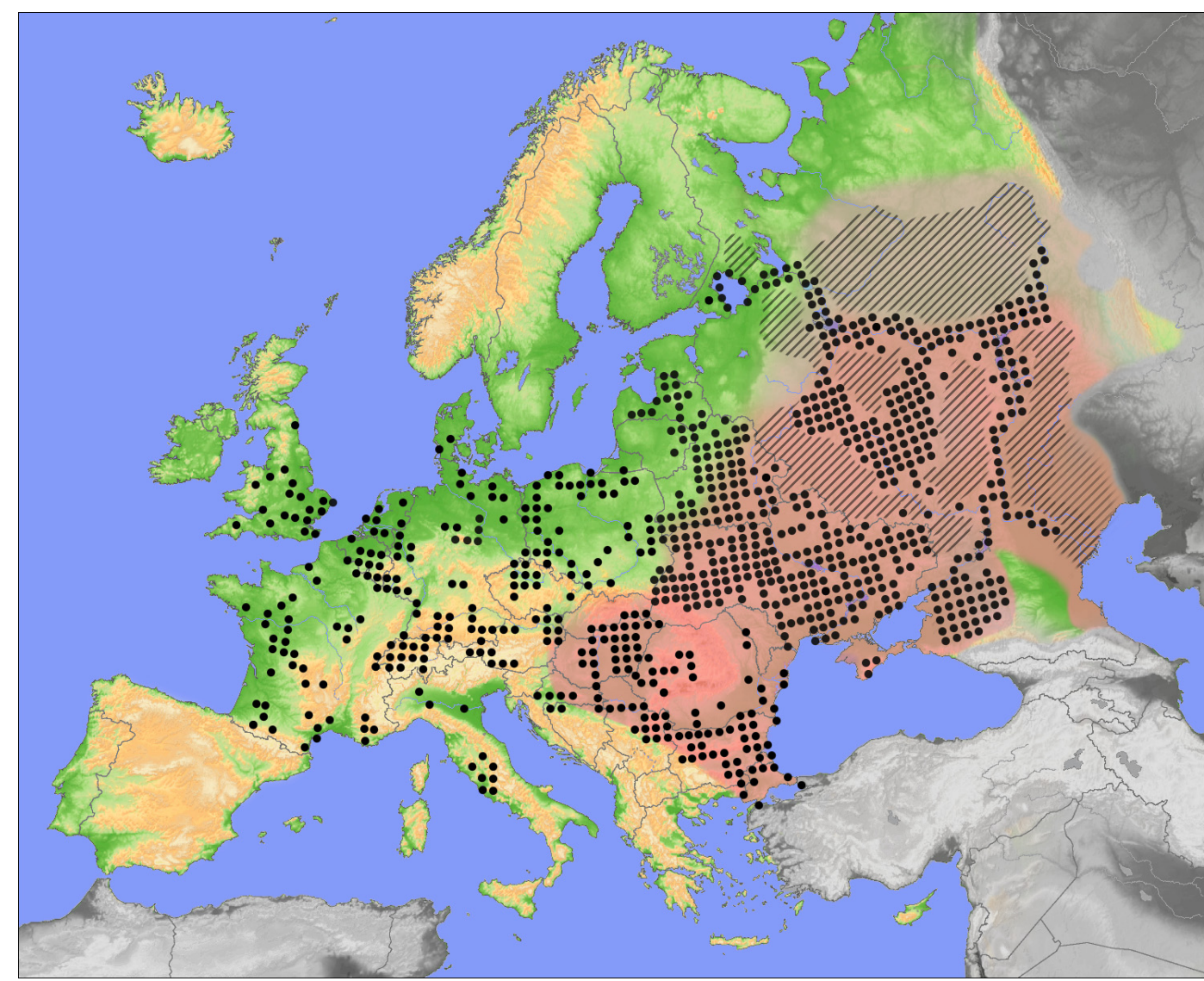

Figure 2

Distribution of Astacus leptodactylus sensu lato (narrow-clawed crayfish) in Europe. Presumed native range is highlighted. Note that the northern boundary of the distribution is very uncertain. The hatched area covers regions where the species is considered widespread but information about specific localities is missing. Narrow-clawed crayfish were considered widely present in the Caspian Sea, particularly in the eastern coastal areas, but present distribution requires updating.

The narrow-clawed crayfish is a widely distributed taxon with its native range in the Pontocaspian river basins. Its most abundant populations are found in Eastern Europe and the Middle East but it has spread to numerous European countries, particularly due to humanmediated translocations in the past. Thus, narrow-clawed crayfish is present across much of the continent except for the southwestern Balkans, Iberian Peninsula, Ireland, Scandinavia, and Estonia (Holdich et al., 2006).

This taxon is found in 32 territories (sensu Holdich et al., 2009) (Table I). Although this number is identical with that in Holdich et al. (2009), we indicated much wider regions with known presence of $A$. leptodactylus in Russia and Ukraine in the map. Unfortunately, no recent records were obtained for the Caspian Sea, so the distribution of narrow-clawed crayfish there is unclear. E.V. Kolmykov referring to Rumyantsev (1974), designated a broad area occupied by one of the taxa associated to narrow-clawed crayfish (Pontastacus eichwaldi) everywhere in the Caspian Sea except for the southern part (www.caspianenvironment.org/biodb/eng/ zoobenthos/Pontastacus\%20eichwaldi/main.htm). The map included in a crayfish stock assessment by Sokolsky et al. (1999) indicated recently confirmed presence of strong stocks in the eastern coastal areas, where this survey was realized, but data from other regions are lacking.

Noticeable refinement of the present distribution of narrow-clawed crayfish is available for southeast Europe, including Bulgaria (Stoynov et al., 2013; Trichkova et al., 2013), Romania, Romanian-Hungarian border (Györe et al., 2013) and Serbia (Simić et al., 2008). In Croatia, narrow-clawed crayfish occurred relatively recently (Maguire and Gottstein-Matočec, 2004) 
and has spread westwards and southwards, displacing both noble and stone crayfish (Maguire et al., 2011). However, in parallel, expanding Orconectes limosus replaces the narrow-clawed crayfish itself (Hudina et al., 2009). Similar displacement of narrow-clawed crayfish has been reported also from Serbia (Simić et al., 2008).

In comparison with maps in Holdich et al. (2006), scattered presence of narrow-clawed crayfish in additional areas out of its native range has also been recorded, e.g., in Latvia and Italy. The distribution of this species in Great Britain has been updated according to Rogers and Watson (2011a). However, the present status of many British populations remains unknown, and some of them might have been already lost due to impacts of NICS, particularly signal crayfish, and associated spread of crayfish plague (J. James, pers. comm.). Because of doubtful population status in Finland (species has not been recorded since 2004; J. Jussila, pers. comm.), we omitted the presumed presence of narrow-clawed crayfish in this country, in accordance with Holdich et al. (2009) who already indicated its likely absence. It is possible that the Finnish population went extinct due to crayfish plague and introduced signal crayfish (M. Pursiainen, pers. comm.). However, the presence of low-density populations cannot be entirely excluded, particularly as it has been repeatedly reported that narrow-clawed crayfish may be able to persist with chronic infections by Aphanomyces astaci (Svoboda et al., 2012; Kokko et al., 2012; Schrimpf et al., 2012).

In many regions of Western Europe, the species distribution certainly remains underestimated. For example, data in sufficient resolution remain unavailable for most of France (see Methods). Similarly, very unbalanced information is available for Germany, in which each federal state is responsible for species distribution monitoring. Frequency and sampling effort vary greatly among them, which makes obtaining a national overview difficult (C. Chucholl, pers. comm.). Complex crayfish-related project in the North Rhine-Westphalia (Germany) (Groß et al., 2008) revealed that narrow-clawed crayfish is more common in this part of the country than previously reported (cf. Holdich et al., 2006). Unfortunately, we failed to obtain an update on Poland, a country where the species is likely more common than the map suggests.

In contrast to Holdich et al. (2006), we reduced the indication of a presumed native range of narrow-clawed crayfish in Poland, Belarus, Finland, Northwestern Russia, and in the proximity of Baltic countries, to exclude upper parts of the river basins belonging to Baltic and White Sea catchments. This modification better reflects the Pontocaspian origin of the species. From a relatively restricted and scattered distribution of narrow-clawed crayfish in those catchments, we believe it is likely that they were colonized only recently, with human aid.

\section{> ASTACUS PACHYPUS RATHKE, 1837; THICK-CLAWED CRAYFISH (FIGURE 3)}

The thick-clawed crayfish has the smallest distribution range of presently recognized indigenous crayfish species in Europe (but this fact may change if some of the recently recognized distinct evolutionary linages within Austropotamobius will be raised to species status in the future; see Klobučar et al., 2013). As the taxonomy of Eastern European crayfish remains open and in a state of flux, we retain the assignment of the thick-clawed crayfish to the genus Astacus, although its separation into a distinct genus Caspiastacus had been proposed in the past (Starobogatov, 1995).

The number of territories (sensu Holdich et al., 2009) from which A. pachypus is reported remains unchanged $(n=4$; Table I). However, the extent of the suggested distribution shown in the presented maps (Figure 3) differs substantially from Holdich et al. (2006). On the one hand, A. Tertyshny (pers. comm.) suggested narrowing of the confirmed presence in eastern part of the Black Sea and in Crimea. On the other hand, M. Schletterer (pers. comm.), reviewing crayfish distributions in Russia, suggested to add records from northeast Azov Sea, as well as the Don river, although the status of these populations (native vs. introduced) is uncertain. Populations in the Caspian Sea are known from Azerbaijan, Russia, Kazakhstan and Turkmenistan; those at eastern coast are considered the strongest (Holdich et al., 2006) and their presence was confirmed relatively recently, in 2011 (V.B. Ushivtsev, pers. comm.). Thus, we make an exception and mark these regions in the map although they do not belong 


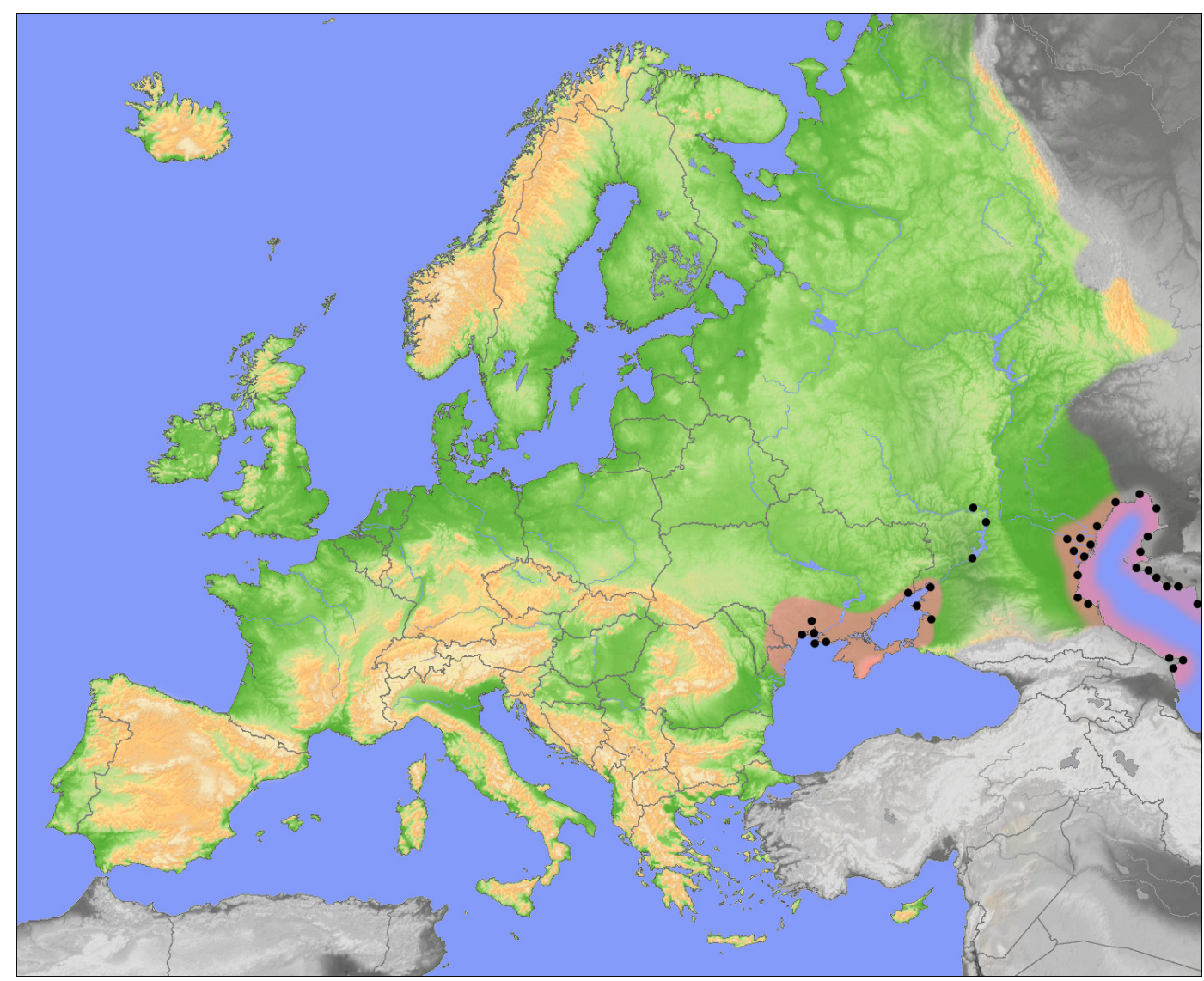

Figure 3

Distribution of Astacus pachypus (thick-clawed crayfish) in Europe. Presumed native range is highlighted; status of populations in the river Don is unclear.

geographically to Europe. We extended the confirmed species range (Cherkashina, 1999; M. Schletterer, pers. comm.) and highlighted the presumed native status of the species in the Caspian Sea (Figure 3). The timing of separation of populations in the Caspian and Black seas, and their extent of divergence, are certainly worth future studies.

Recent population and distribution trends of $A$. pachypus are to some extent speculative. On the one hand, the absence of commercial crayfish harvest and reduced predatory pressure due to the decrease in the number of fish feeding on crayfish (beluga, catfish, zander) resulted in an increase of crayfish stocks in the Caspian Sea (E.V. Kolmykov: www.caspianenvironment.org/biodb/eng/zoobenthos/Pontastacus\%20eichwaldi/ main.htm). On the other hand, existing data suggest that the Volga is substantially polluted, being one of the principal sources contaminating the Caspian Sea. Furthermore, the magnitude of oil extraction and transport activity that constitute risks to water quality is still increasing (Korshenko and Gul, 2005; CEP, 2009). These factors have been suggested as responsible for scarcity of thick-clawed crayfish in the northern and western parts of the Caspian Sea (Holdich et al., 2006). The presumed ongoing changes in A. pachypus distribution and the lack of recent reliable records indicate that a thorough monitoring across the range of this species is warranted.

\section{> AUSTROPOTAMOBIUS PALLIPES SPECIES COMPLEX; WHITE-CLAWED CRAYFISH (FIGURE 4)}

The presently prevailing view on taxonomy of the white-clawed crayfish considers it a species complex formed by two distinct species $A$. pallipes and $A$. italicus, this conclusion being 


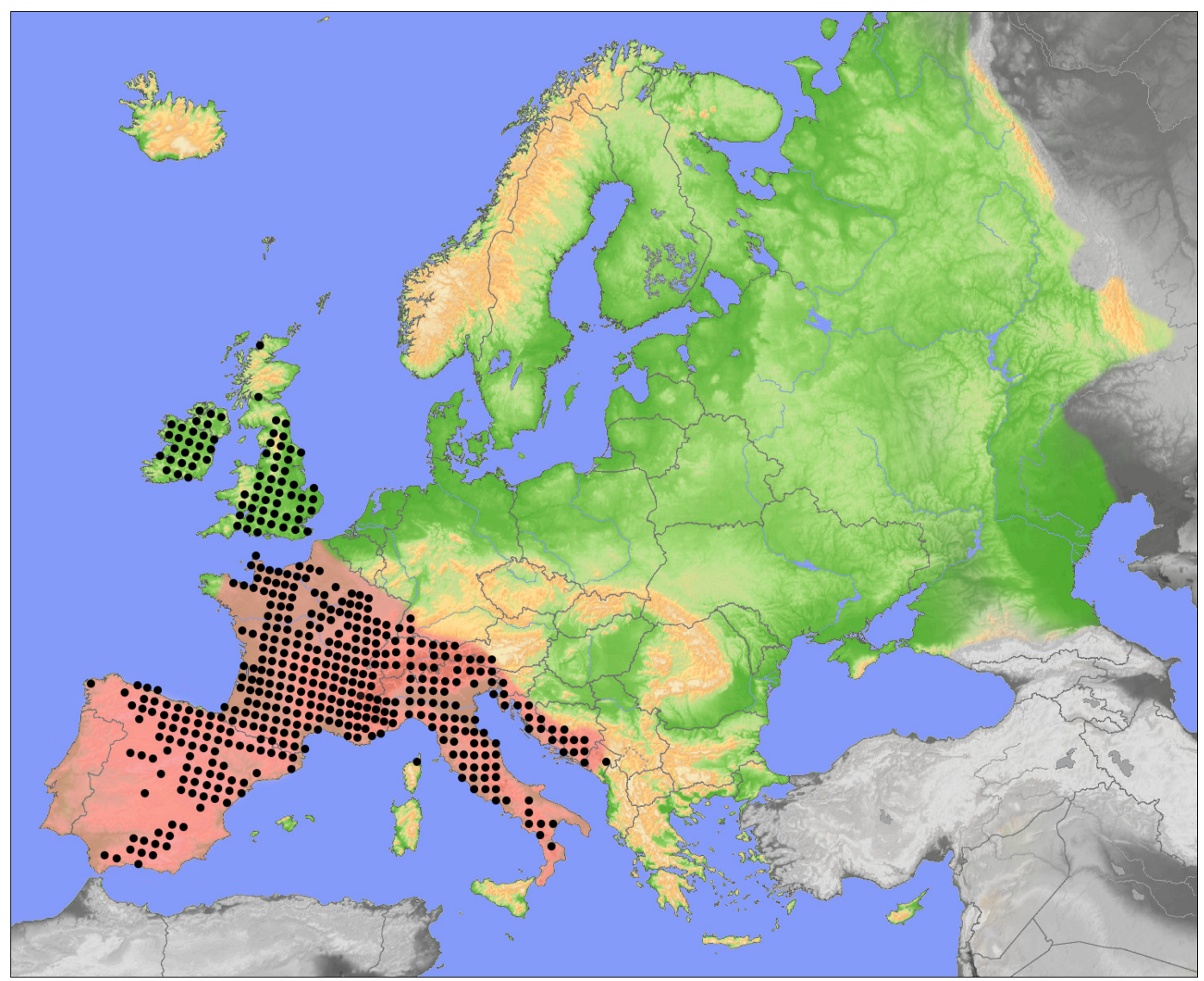

\section{Figure 4}

Distribution of Austropotamobius pallipes species complex (white-clawed crayfish), including populations assigned to both A. pallipes and A. italicus, in Europe. Presumed native range is highlighted.

based on results of various molecular analyses (e.g., Santucci et al., 1997; Grandjean et al., 2002; Pedraza-Lara et al., 2010). Earlier molecular analyses even suggested that at least some of the subspecies described within white-clawed crayfish are differentiated at mitochondrial markers (e.g., A. pallipes bispinosus, A. italicus italicus, A. i. carinthiacus; Fratini et al., 2005) but later detailed analyses do not fully support this view (Pedraza-Lara et al., 2010). The differentiation between $A$. italicus and $A$. pallipes at the nuclear genome level has been recently challenged by Chiesa et al. (2011) in an analysis using amplified fragment length polymorphism (AFLP). For our purpose, we follow Holdich et al. $(2006,2009)$ and include populations assigned to both $A$. pallipes and $A$. italicus in the distribution map (not differentiating between the two).

Genetic analyses contributed not only to advances in systematics of white-clawed crayfish but also to re-assessments of its presumed native status. Studies demonstrating low variation at mitochondrial markers suggested that populations in the Iberian Peninsula (belonging to $A$. italicus) had been introduced there by humans (Grandjean et al., 2001; Trontelj et al., 2005). However, more detailed analyses revealed higher variation than previously assumed and suggested substantially longer presence of the species in this region (Beroiz et al., 2008; Diéguez-Uribeondo et al., 2008; Matallanas et al., 2011, 2013). Patterns suggesting bottlenecks, previously ascribed to human mediated introductions, are interpreted by survival in small-scale glacial refugia (Pedraza-Lara et al., 2010) and recent population crashes due to crayfish plague outbreaks and other negative factors (Matallanas et al., 2011, 2013). We thus consider the native range of the white-clawed crayfish complex to encompass the Iberian Peninsula (Figure 4).

Similar discussions have been raised in the past about the status of $A$. pallipes in England. It is generally considered an indigenous species for the UK, and for conservation purposes 
the clear evidence of having been present in the country prior to the year 1500 is sufficient (Holdich et al., 2009). However, crayfish introduction from France in Middle Ages is a plausible scenario for its presence in England, and genetic data, while confirming a close relationship between crayfish populations in England and northern France (Grandjean et al., 1997; Santucci et al., 1997; Gouin et al., 2001), are inconclusive regarding the distinction between natural and human-mediated colonization. Thus, British Isles are not included in the original range of $A$. pallipes in our maps.

Recently confirmed number of territories inhabited by white-clawed crayfish $(n=18)$ has been increased by one since Holdich et al. (2006), as an apparently introduced population was found in Sardinia (S. Bertocchi, unpubl. data). Wider presence has been recently documented in Bosnia and Herzegovina (Trožić-Borovac, 2011). Although once widely distributed throughout Western and Southern Europe, white-clawed crayfish recently face a substantial pressure across its entire area. Widespread presence of Old NICS associated with crayfish plaque outbreaks, habitat losses, and other anthropogenic impacts are responsible for population declines in many countries (e.g., Italy, Spain, and France). Particularly in England and Wales, these changes are well documented (see Holdich et al., 2009; Rogers and Watson 2011a, 2011b), and situation up to 2010 is reflected in the maps. However, the gradual losses of $A$. pallipes continue, corresponding to spread of $P$. leniusculus in Great Britain as documented by Holdich et al. (2014).

It is ironic that the "Isle of Good Hope" for white-clawed crayfish is nowadays Ireland, an island where the species has been introduced by humans (Grandjean et al., 1997; Gouin et al., 2003). Recently available distribution data even supports partial extension of its presence in Northern Ireland (Natural England, 2013). At present, the white-clawed crayfish status is considered as "favourable" in the Republic of Ireland by National Parks \& Wildlife Service (NPWS, 2013). We have to hope that the island will avoid introduction of invasive crayfish species, and that the 1980s crayfish plague episode (Reynolds, 1988) will not be repeated.

\section{>AUSTROPOTAMOBIUS TORRENTIUM (SCHRANK, 1803); STONE CRAYFISH (FIGURE 5)}

For the present purpose, we consider the stone crayfish a single species. However, the findings of Trontelj et al. (2005) and especially Klobučar et al. (2013), who uncovered several divergent, geographically restricted phylogroups concentrated mainly in the northern-central Dinaric region, are likely to raise a debate about the systematic and nomenclatural status of this taxon. It is possible that some of these apparently relict old lineages will be raised to their own rank (which might be beneficial for their conservation).

The presence of stone crayfish has been at present confirmed in at least 20 countries of Central and Southeastern Europe (Table I). Although many populations of the species declined across its range, ongoing astacological research confirmed its wider presence in Bosnia and Herzegovina (Trožić-Borovac, 2011), Serbia, and Montenegro (Simić et al., 2008), as well as in Germany (Groß et al., 2008; Martin et al., 2008a). Substantial number of additional records has been also provided for previously underrepresented Romania (Pârvulescu and Zaharia, 2012; Pârvulescu et al., 2013), and the presumed original range of stone crayfish has been expanded to cover the Carpathian Arch there. All bulgarian Natura 2000 localities were recently investigated for presence of stone crayfish by Todorov et al. (in press).

The distribution and presumed original range in the upper Elbe basin in the Czech Republic and Saxony was also updated. Data points reflect additional Czech populations reported in Vlach et al. (2009), and discovery of a stone crayfish population close to Dresden, Germany (Martin et al., 2008a). The range was adjusted based on genetic data suggesting that the disjunct easternmost Czech population has been likely stocked by humans (Pešek, 2013).

An isolated population of stone crayfish has been reported from Haute Savoie, France, and this is now indicated in the map. Interestingly, a genetic analysis revealed presence of a divergent haplotype corresponding to one of the distinct clades present in Dinaric Karst (Grandjean, 2012), suggesting a likely translocation in the past. 


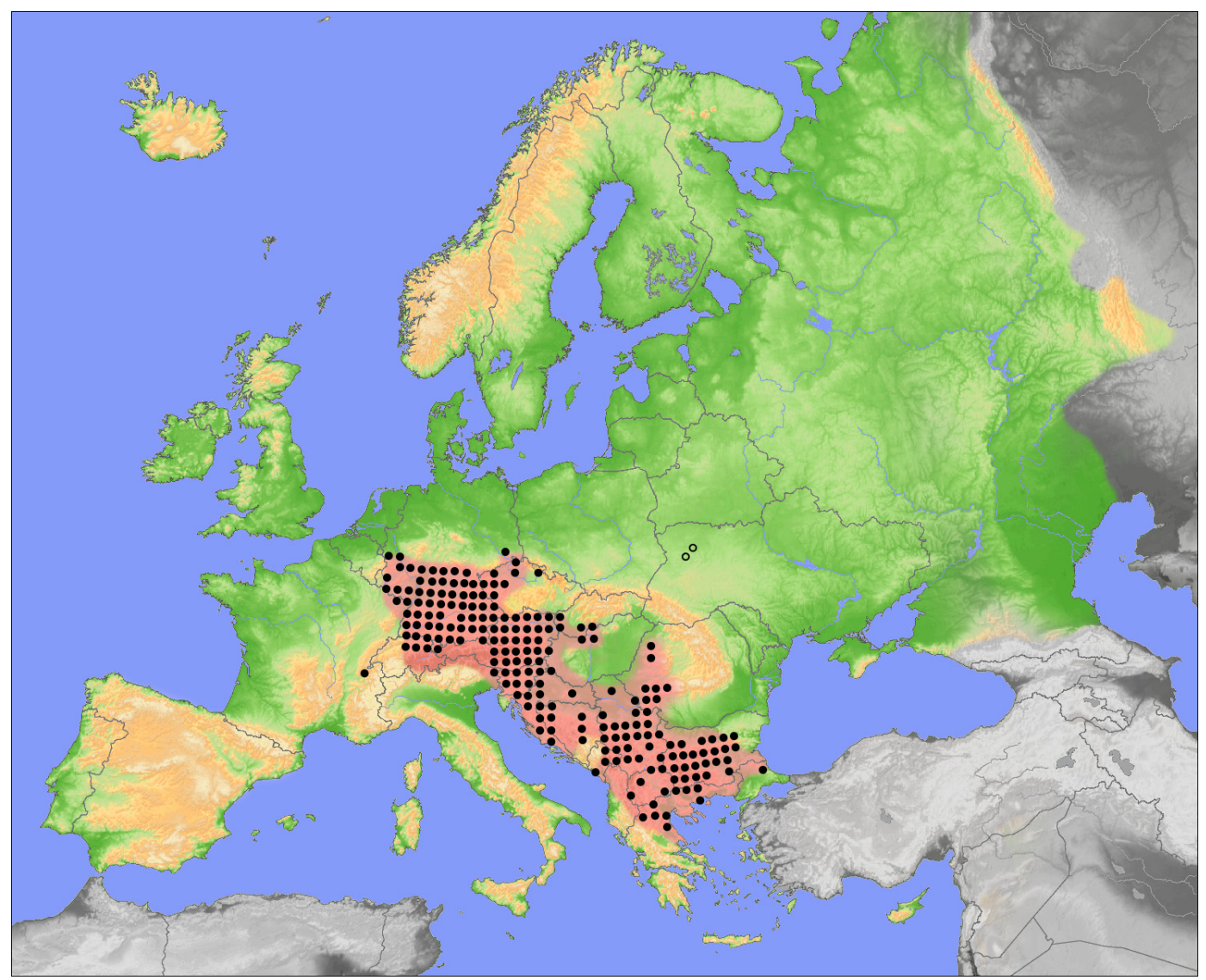

\section{Figure 5}

Distribution of Austropotamobius torrentium (stone crayfish) in Europe. Presumed native range is highlighted. Open circles indicate a doubtful report from Ukraine that should be corroborated.

Furthermore, we indicated as open for corroboration the presumed presence of $A$. torrentium in the Stokhod River, Ukraine suggested in Starobogatov (1995). Machino and Holdich (2006) provided reasonable arguments against this record; however, we believe that a targeted astacological survey, especially in the upper parts of this catchment, would be beneficial to provide evidence from the field.

\section{OLD NON-INDIGENOUS CRAYFISH SPECIES}

Three crayfish species of North American origin have been introduced to Europe between 1890 and the mid-1970s, and became widespread across the continent. These "Old NICS" (Holdich et al., 2009) are treated below, in the order of their introductions.

\section{> ORCONECTES LIMOSUS (RAFINESQUE, 1817); SPINY-CHEEK CRAYFISH (FIGURE 6)}

The spiny-cheek crayfish has been recently reported from 22 European territories (Table I), as its occurrence was confirmed also in Spain (Muga River basin) close to the border with France (Benejam et al., 2011). Although the increase since Holdich et al. (2009) does not seem significant, the number of known populations in already invaded regions has augmented as well (both due to the species' spread and increased survey efforts), and its further expansion was recorded. This is particularly significant in the river Danube, through which the species has entered Romania and quickly spreads downstream (Pârvulescu et al., 2009, 2012), so its occurrence in Bulgaria may be expected in near future. In case of Romania, further invasion 


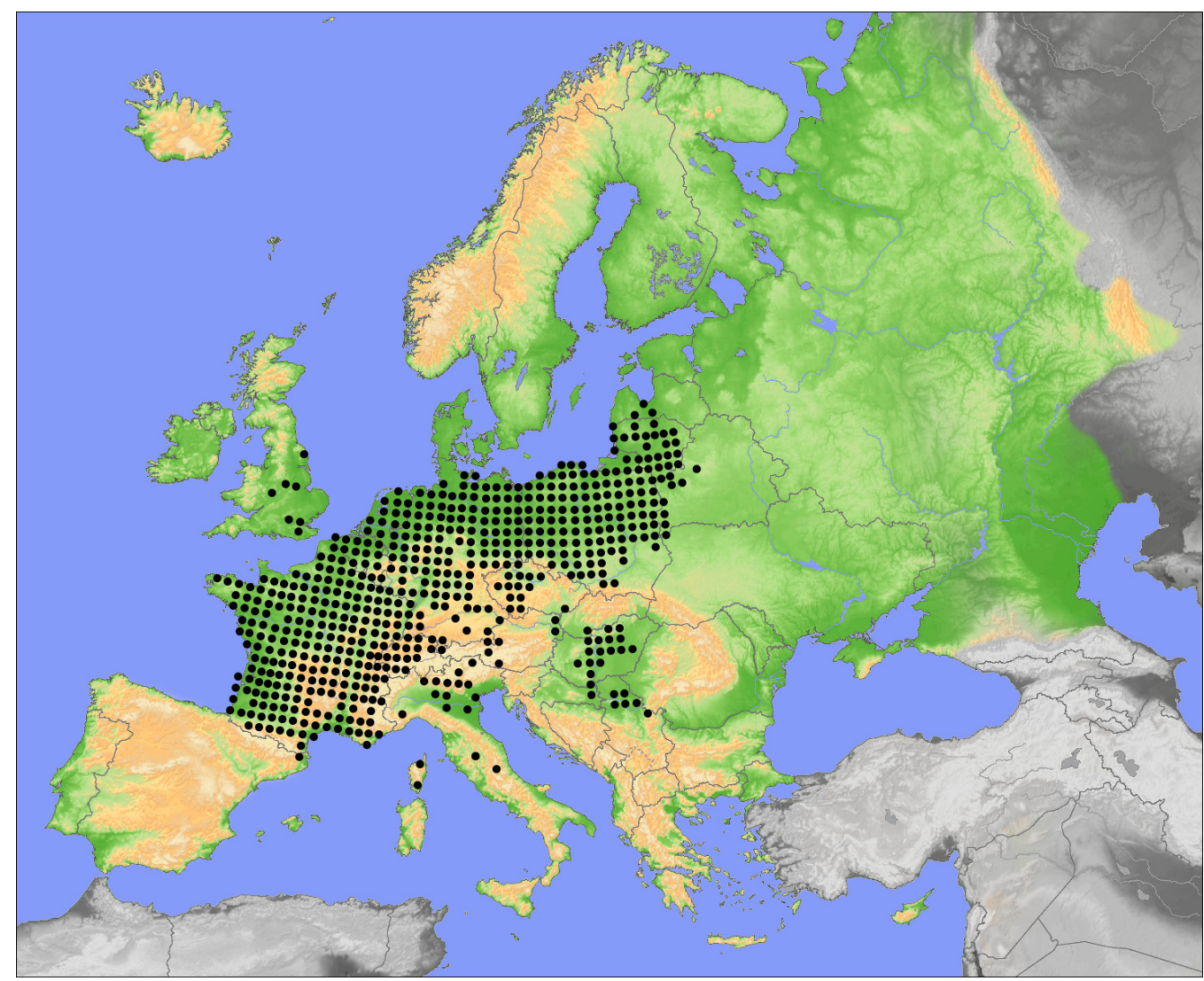

Figure 6

Distribution of Orconectes limosus (spiny-cheek crayfish) in Europe.

wave might appear also in northwestern part of country due to upstream spread of spinycheek crayfish from the Tisza basin in Hungary via the Körös (Cris) River (Györe et al., 2013), or in the west through the Danube tributary Tamiš, in which it was recently recorded in Serbia (Lipták et al., 2013).

Substantial distribution expansions of spiny-cheek crayfish and related losses of ICS have been reported from Belarus (Aklehnovich and Razlutskij, 2013), Lithuania (Arbačiauskas et al., 2011a, 2011b) and Latvia (Briede, 2011), as well as Germany (Groß et al., 2008; Martin et al., 2008b), Hungary (Györe et al., 2013), and Italy (Aquiloni et al., 2010). We expect further upstream spread of spiny-cheek crayfish in the Vistula Basin (Poland; cf. Holdich et al., 2006). This might result in invasion of Ukraine as hypothesized by Son et al. (2013), particularly via the Western Bug River. Indeed, an upper part of this basin (Lesnaya Levaya River) was found already invaded by spiny-cheek crayfish in Belarus (Aklehnovich and Razlutskij, 2013). In a longer term perspective (but potentially accelerated by human-mediated translocations), Ukraine might be also reached via Romania through the lower Danube and consequent upstream spread in its tributaries. Further highly possible pathway may go via already invaded Tisza in Hungary.

Within Hungary, colonization of Lake Balaton seems likely in the near future; a dead specimen has been already found in the lake (Bódis et al., 2012), and spiny-cheek crayfish were recently reported in a fishpond in the lake vicinity (Ferincz et al., 2014).

\section{> PACIFASTACUS LENIUSCULUS (DANA, 1852); SIGNAL CRAYFISH (FIGURE 7)}

With 29 invaded territories, the signal crayfish is the most widespread NICS in Europe. Since Holdich et al. (2006), its presence was reported from five new territories. These are Slovakia, Norway, and Croatia reported by Holdich et al. (2009), and recently added Estonia, and Russia. 


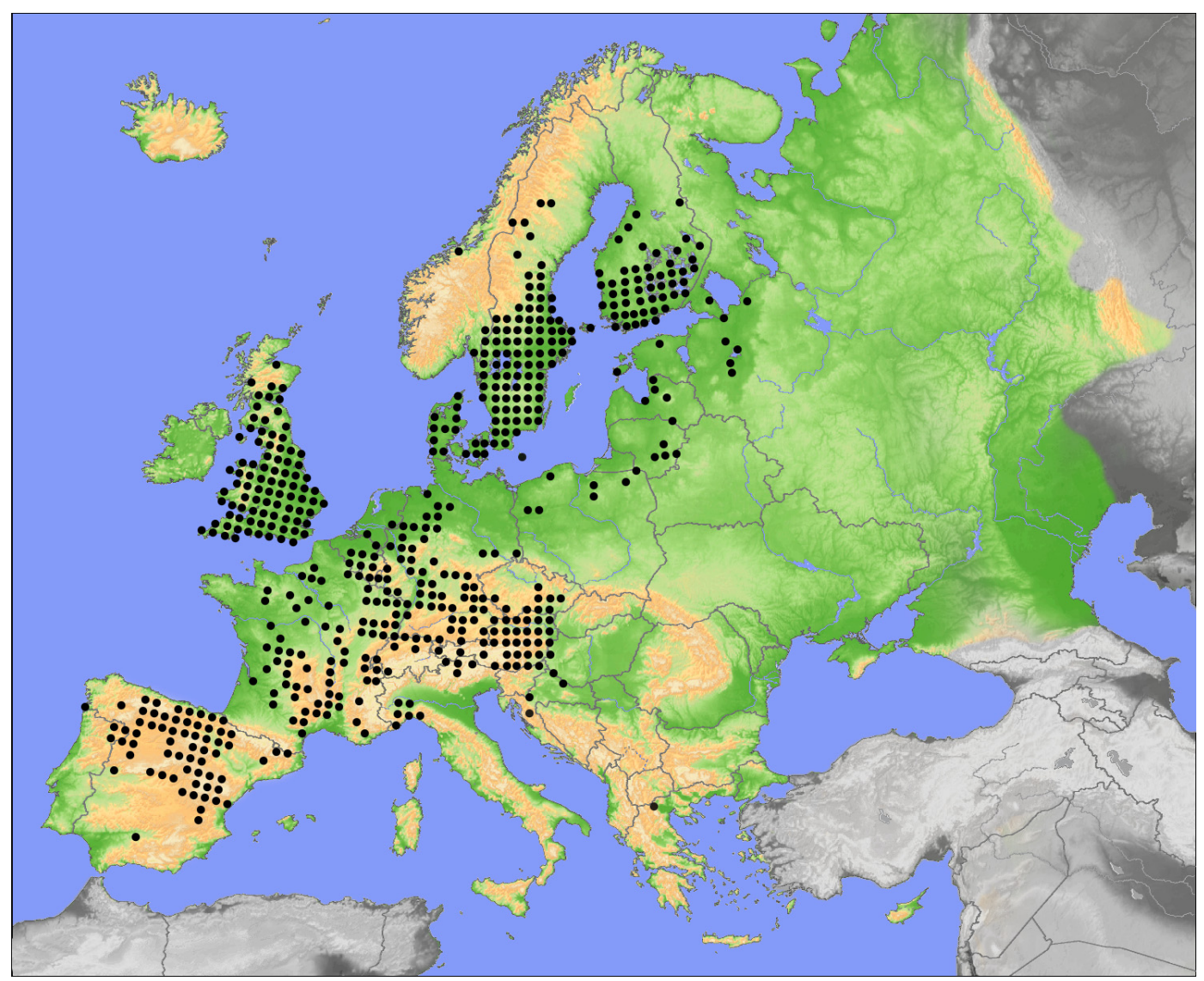

Figure 7

Distribution of Pacifastacus leniusculus (signal crayfish) in Europe.

The presence of signal crayfish, originating likely from introduction by Austrian fishermen or invasion from waterbodies in Austria, was confirmed in the border stretch of the river Morava between Slovakia and Austria in August 2006 (Petrusek and Petrusková, 2007), and since then the species has been observed in various backwaters of this river in Slovakia (E. Stloukal, pers. comm.). So far, however, the species apparently did not spread further, either upstream to the Czech Republic or inland into Slovakia. Although original analyses did not suggest the infection by $A$. astaci (Petrusek and Petrusková, 2007), subsequent use of a more sensitive molecular method detected presence of the pathogen in this population (Kozubíková et al., 2011).

In the same year, crayfish plague-carrying $P$. leniusculus were found for the first time also in Norway, in the Dammane area of the Telemark County in October 2006 (Johnsen et al., 2007). In 2008, this population was eradicated by cypermethrin-based pesticide BETAMAX VET (Sandodden and Johnsen, 2010). In 2009, signal crayfish were found also in four small ponds (golf course dams) close to Oslo, and eradicated by the same means. Eradication in both cases seems to be successful (S.I. Johnsen, pers. comm.). Unfortunately, heavily infected signal crayfish population was also recorded in the Halden watercourse (Lake Øymarksjøen) in 2008 (Vrålstad et al., 2011). Most recent findings even refer to introductions in the central part of the country.

As a consequence of introductions in Austria in the 1970s, signal crayfish invaded rivers Mura (in 2003) and Drava (in 2007) in Slovenia (Vrezec et al., 2013) and later (in 2008) was recorded for the first time in the Croatian part of the Mura (Maguire et al., 2008). Its expected invasion through the Drava river catchment (it has entered the Drava also from the Mura in Croatia; Maguire et al., 2011) has the potential to spread into the vast majority of water bodies in Northeastern Croatia (Hudina et al., 2009, 2011; Maguire et al., 2011). Furthermore, signal 
crayfish presence was recorded in 2012 in the Korana, a karstic river of the Sava river basin, where it has been deliberately introduced (Hudina et al., 2013).

In 2008 and 2010, two small populations of signal crayfish were recorded in Estonia (M. Hurt and T. Paaver, pers. comm.). Unfortunately, one of these is located in a noble crayfish-rich island Saaremaa (Paaver and Hurt, 2009).

Holdich (2002) mentioned an attempt to introduce $P$. leniusculus in the north-west of Russia (Leningrad and Pskov regions), but this was considered unsuccessful. Recently, M. Schletterer (pers. comm.) after reviewing literature and seeing local fishermen with signal crayfish on markets suggested its presence in the Leningrad and Novgorod regions. This seemingly unexpected finding is not so surprising after closer consideration. As already mentioned, signal crayfish is particularly widespread in Europe, especially due to legal or illegal introductions that usually aim for future exploitations of stocks. Thus, Russia is unlikely to be an exception, especially as strong signal crayfish populations occur for decades in neighbouring Finland and natural migration barriers are limited in this region. Even geopolitical division of Europe by the Iron Curtain did not prevent introductions from Sweden to former Soviet Bloc countries, e.g., to Lithuania (then part of the Soviet Union) in 1972 (Cukerzis, 1979) and to former Czechoslovakia in 1980 (Policar and Kozák, 2000).

Signal crayfish are particularly widespread in Sweden, Finland and England. Their illegal introductions are constantly reported across Europe but geographically well noticeable spread appears in Scandinavia. A further spread northwards in comparison with maps in Holdich et al. (2006) is apparent in Sweden. Signal crayfish are now common also in Danish streams (Skov et al., 2011) and their spread to additional waterbodies is expected. Particularly alarming are records of signal crayfish from isolated areas including islands (Bornholm, Funan, and Zealand), which must have resulted from intentional introductions (S. Berg, pers. comm.). Signal crayfish are also gaining more and more territories in England and Scotland (Rogers and Watson 2011a, 2011b; Holdich et al., 2014).

Based on detailed crayfish-related surveys in a few federal states of Germany, substantial range expansion is expected in this country, as well as in France, where it colonized some $80 \%$ of the departments (M. Collas, pers. comm.). Confirmed records are on increase also in the Czech Republic, Austria, and Latvia. It might be thus assumed that despite relatively modest distribution presented on the map, similar situation can be expected in Poland from which we lack any recent data. Further alarming records come from Lithuania. Rakauskas et al. (2010) reported established signal crayfish populations in the Žeimena River; Arbačiauskas et al. (2011a) later confirmed its occurrence also in its tributary Mera. Spread in these catchments, which both belong to the Neris River basin, and further expansion in the Neris itself, might result in invasion of Belarus.

Only few records of signal crayfish are so far confirmed in south-eastern Europe but some changes are reflected in the map. For Italy, introduction to Brugneto Lake in 2002 is indicated (Capurro et al., 2007), as well as further records recently reported from this area (E. Tricarico, pers. comm.). Historical presence in the north-western Greece (River Kalamas) was omitted as this introduction was unsuccessful (Koutrakis et al., 2007). Unfortunately, the other population introduced in 1987 to the artificial Lake Agra, northern Greece, escaped from the outflow and is now thriving in the river (C. Perdikaris, pers. comm.).

\section{>PROCAMBARUS CLARKII (GIRARD, 1852); RED SWAMP CRAYFISH (FIGURE 8)}

Although the number of territories invaded by the red swamp crayfish (15; Table I) has not changed recently, expansion of red swamp crayfish is evident across its distribution in Europe. In addition to heavily invaded Portugal and Spain (Holdich et al., 2009; Oscoz et al., 2010), new confirmed records show strong increase of this species' presence in Italy (Aquiloni et al., 2010) and substantially higher coverage of the Netherlands (Koese and Soes 2011). Survey in the North Rhine-Westphalia (Germany) also resulted in substantial changes in known distribution of this species in the region (Groß et al., 2008), although it is not clear to what extent this is due 


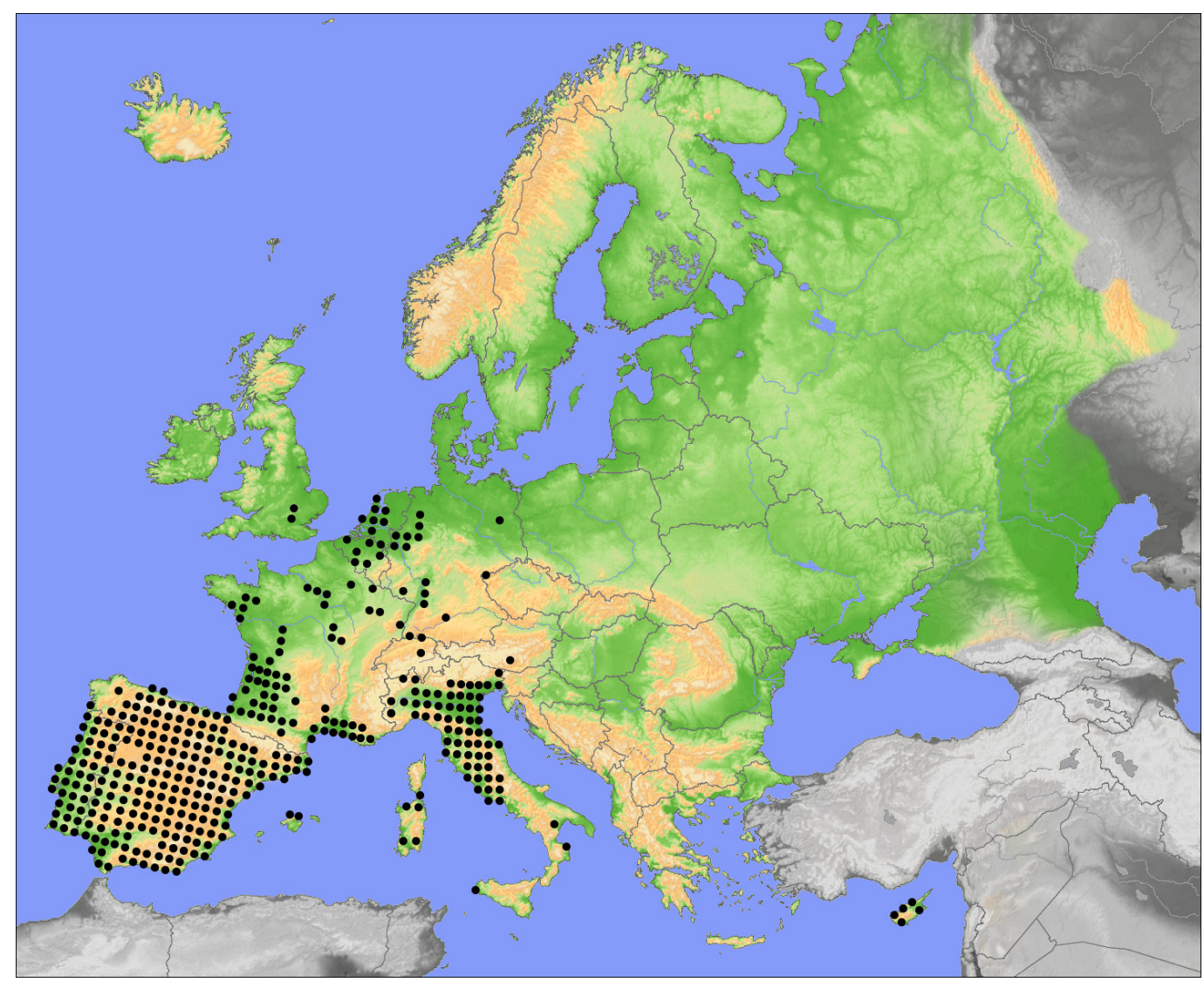

Figure 8

Distribution of Procambarus clarkii (red swamp crayfish) in Europe.

to improved knowledge, and what results from recent expansion. While data from most other German federal states are less accessible, we may expect to some extent similar situation in further parts of the country with suitable climatic conditions, especially as Chucholl (2011) demonstrated the ability of this species to withstand low temperatures in southern Germany by modulating its life history and reproductive patterns.

Red swamp crayfish recently appeared in Flanders, Belgium (Boets et al., 2012) and Ellis et al. (2012) reviewed and predicted its future occurrence in the Thames River Basin. Additionally, the presence of the species is known from dams of Asprokremmos and Evretou in Cyprus. Occurrence in four more dams which dry out substantially or completely in summer has been also suggested, but the recent status of these populations is unknown (C. loakeimidis and C. Perdikaris, pers. comm.). However, temporary nature of these habitats may not be necessarily limiting for the red swamp crayfish thanks to its burrowing abilities.

Unfortunately, the recent status of the red swamp crayfish in France is not reflected well in the map (Figure 8). The situation shown by Holdich et al. (2006) principally follows the situation presented by Collas et al. (2007). At that time, red swamp crayfish species was reported from ca. $20 \%$ of French departments, with the strongest populations in the southwestern part of the country. The recent situation has changed substantially, and the species is known from around three quarters of the departments (M. Collas, pers. comm.). However, the data summarize mainly the presence/absence of the species, and such information is not sufficiently precise for updating the map.

\section{> NEW NON-INDIGENOUS CRAYFISH SPECIES}

Since the 1980s, several additional crayfish species got established in European waters, mostly thanks to aquarium or aquaculture trade. These "New NICS" include at present two 


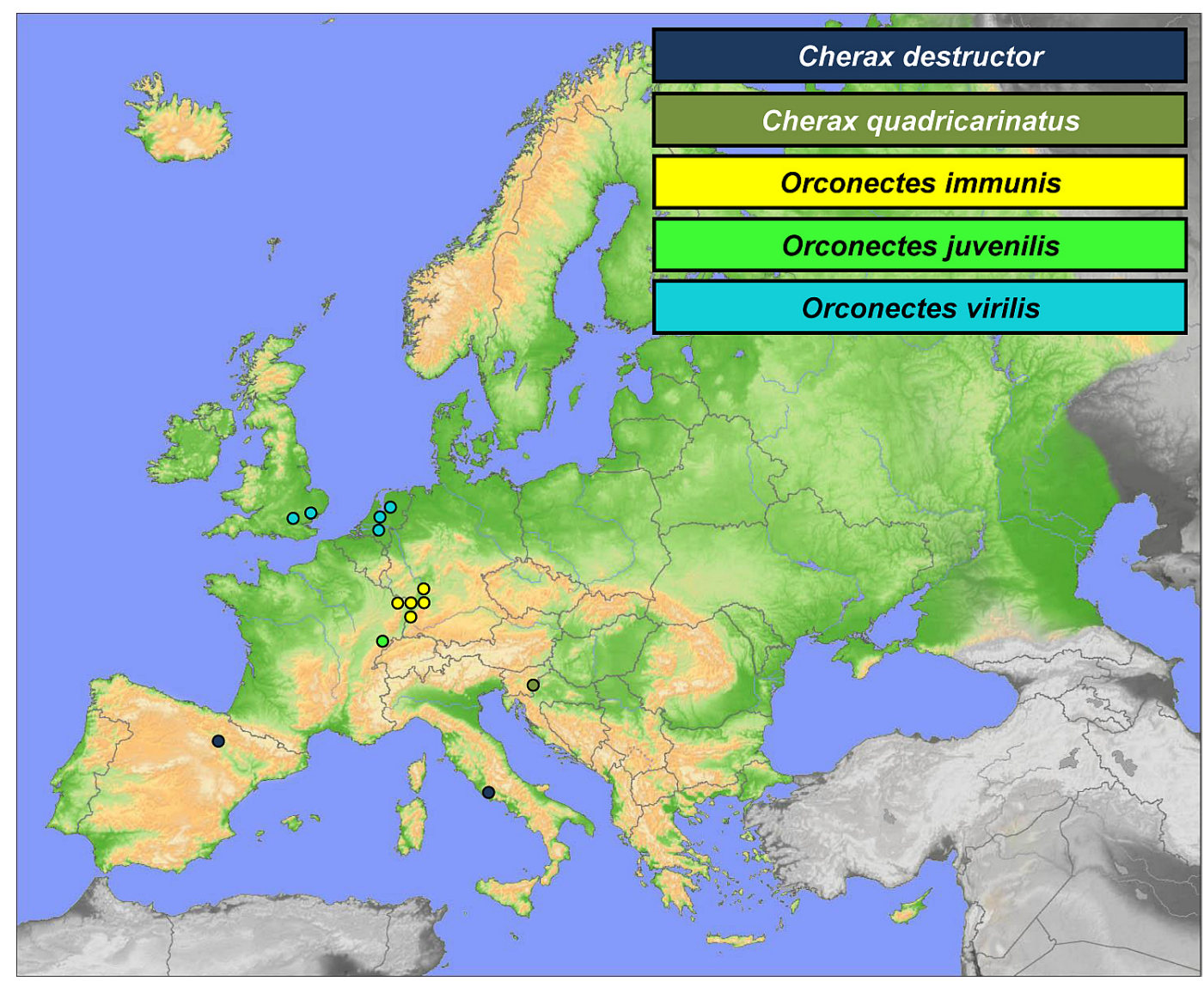

Figure 9

Distribution of the New NICS (Cherax spp. and Orconectes spp.) in Europe. Occasional one-time findings of Cherax are not indicated.

Australian species of the genus Cherax (Parastacidae), and at least five North American species of the family Cambaridae (genera Orconectes and Procambarus). Releases of additional species kept as ornamental pets in aquaria are likely (see Chucholl, 2013), and considerable uncertainty about taxonomy of some of the established North American taxa still remains (Filipová et al., 2010, 2011).

\section{> CHERAX DESTRUCTOR CLARK, 1936;" YABBY (FIGURE 9)}

Due to aquaculture interests, the yabby was firstly introduced into Northern Spain from California in 1983 (Bolea, 1996). Its populations became established in autonomous communities Navarra and Aragón (Holdich et al., 2006). Later, four populations have been successfully eradicated by intentional introduction of the crayfish plague pathogen (J. Dieguéz-Uribeondo, pers. comm.). However, this species might have been translocated to other places in this region. To our knowledge, there is at least one recently confirmed Spanish population, occurring in a small irrigation pond close to Bagüés, province Zaragoza, Aragón (A. Mestre, pers. comm.).

Since the early 1990s, both yabby and redclaw (C. destructor and C. quadricarinatus, respectively) are intensively farmed in Italy (D'Agaro et al., 1999). Scalici et al. (2009) reported an established population in the Natural Preserve of "Laghi di Ninfa" (central Italy). The animals were probably introduced at the end of the 1980s to foster an experimental aquaculture. It seems likely that the low temperature of the surrounding waters prevent further natural spreading of crayfish; however, barriers against their intentional translocation into other waters are weak. Absence of neighbouring populations make eradication of this stock still 
feasible and economically profitable when compared to the costs that this species might inflict if allowed to spread (Gherardi et al., 2011).

Distribution changes suggested above are reflected in Figure 9. Yabbies were repeatedly reported also from fish markets, restaurants, and pet shops across further European countries; however, additional established populations were not confirmed (Holdich et al., 2006, 2009; Chuchol, 2013 and references therein). A potential for spread of this species in European inland waters is limited due to its temperature requirements as well as susceptibility to crayfish plague; however, its high invasiveness should not be ignored (Tricarico et al., 2010).

\section{> CHERAX QUADRICARINATUS (VON MARTENS, 1868); REDCLAW (FIGURE 9)}

As mentioned above, the redclaw has been involved in intensive farming in Italy since the early 1990s (D'Agaro et al., 1999). Marino et al. (2014) recently reported a crayfish plague outbreak in farmed redclaw in Sicily. The most likely source of the disease was the red swamp crayfish. Unfortunately, the farm owner decided to wipe out all crayfish present in the facility, carefully disinfected the tanks, and started production of the red swamp crayfish itself.

Due to redclaw high availability through the aquarium and live food trade, it has been repeatedly reported in wild, particularly in the Netherlands, Great Britain, and Germany. However, none of these records provided evidence on established population (Soes, 2008; Holdich and Sibley, 2009; Holdich et al., 2009). Up to now, the only one self-sustaining population has been found in the oxbow lake Topla in eastern Slovenia in 2009. The temperature at the locality is elevated thanks to thermal springs, and gradually decreases towards the outfall to the river Sava. The bulk of the redclaw population with sexually mature individuals was restricted to the part of the oxbow with temperatures between 21 and $31{ }^{\circ} \mathrm{C}$. Population has been spreading in the lake but invasion to adjacent river is unlikely under current climatic conditions (Jaklič and Vrezec, 2011). No eradication of this population is being planned (A. Vrezec, pers. comm.).

\section{> ORCONECTES IMMUNIS (HAGEN, 1870); CALICO CRAYFISH (FIGURE 9)}

Orconectes immunis, called calico or papershell crayfish, was first reported in Europe from two locations in the Upper Rhine system, southern Germany, in the mid-1990s (Dehus et al., 1999; Gelmar et al. 2006). Its introduction pathway is unclear, and both an introduction from aquaria (Dehus et al., 1999; Lodge et al., 2012) and as a fishing bait were suggested (Gelmar et al., 2006). However, this species was not known in the pet trade prior to its confirmed presence in the Upper Rhine plain (Gelmar et al., 2006), making an introduction as fishing bait (possibly by Canadian soldiers, who had been stationed at an airbase near the two localities where the species was first discovered) more likely (Chucholl, 2013). Since its discovery, the calico crayfish has rapidly spread upstream and downstream in the Upper Rhine system and colonized over $100 \mathrm{~km}$ long stretch. Later (in 2010), it appeared also in the basin of the Moder, Bas-Rhin department, France. Circumstances of this introduction are unknown (Collas et al., 2011) but the source in the Rhine can be assumed, as the genetic data clearly show that French and German populations are of the same origin (Filipová et al., 2011). Interestingly, substantial divergence between $O$. immunis from European populations and reference sequences of presumably the same species were observed, suggesting that this taxon may represent a species complex in its original range (Filipová et al., 2011).

Spread of calico crayfish in the Rhine basin is relatively well documented and has been recently reviewed by Chucholl (2012). It successfully invaded several types of both lentic and lotic habitats where it became abundant. Its invasiveness fits well with its life history showing typical signs of r-strategy (e.g., high growth rate, early maturation, high fecundity) and omnivorous feeding habits. Calico crayfish also digs deep burrows, which allow it to occupy shallow and temporary water bodies (Chucholl, 2009, 2012). Furthermore, O. immunis dominates in direct interactions and is superior in competition for shelter with spiny-cheek crayfish; 
the population of the latter, established for decades in the Rhine, become widely displaced by the new invader where their ranges overlap (Chucholl et al., 2008). The calico crayfish has been recently confirmed as a carrier of the crayfish plague pathogen in the wild (Filipová et al., 2013; Schrimpf et al., 2013a).

\section{> ORCONECTES JUVENILIS (HAGEN, 1870); KENTUCKY RIVER CRAYFISH (FIGURE 9)}

The first record of a Kentucky River crayfish population in Europe was in the Dessoubre River, a tributary of the Doubs, eastern France, in 2005 (Collas et al., 2007). Crayfish were found in two ponds adjacent to a restaurant which advertises crayfish as a delicacy. The crayfish Atlas originally referred to Orconectes rusticus (Holdich et al., 2006); however, morphological examination of form I males caught in 2007 revealed that the species is in fact Orconectes juvenilis (Chucholl and Daudey, 2008), a taxon only recently elevated to species rank (Taylor, 2000). This determination has been also confirmed by DNA barcoding (Filipová et al., 2011). The introduction itself probably happened at least a few years before the species has been reported, as the restaurant ponds, which served as a source for invading at least a $700 \mathrm{~m}$ long stretch of the downstream river, possessed well developed population in 2006. In 2007, an unsuccessful attempt was carried out to eradicate the pond population by intensive trapping (Chucholl and Daudey, 2008). We are not aware of any recent information on the status of this population. Considering the ability of downstream spread of most known NICS, its presence in a larger stretch of the invaded river, and possibly mouths of its smaller tributaries, may be expected.

\section{> ORCONECTES CF. VIRILIS; VIRILE CRAYFISH (FIGURE 9)}

Thanks to broad native range and extensive introductions, the virile (or Northern) crayfish was considered the most widespread crayfish species in the United States and Canada, inhabiting over 40 states (Taylor et al., 2007). However, recent phylogeographic and phylogenetic studies revealed that it is actually a diverse species complex (Mathews and Warren, 2008; Mathews et al., 2008). The genetic analysis of European populations suggested that they represent a lineage distinct from O. virilis in a strict sense (Filipová et al., 2010).

The first report of virile crayfish from European waters is from the Netherlands in 2004. However, by that time it was already widespread, so its introduction must have happened some years earlier. Although virile crayfish were occasionally offered by aquarium and garden pond wholesalers, the initial introduction pathway remains unknown. The species was confirmed from numerous sites and colonized several hundred kilometres of waterways by 2006, even displacing spiny-cheek crayfish in some sites (Soes and van Eekelen, 2006; Soes and Koese, 2010; Koese and Soes, 2011).

In 2004, a breeding population of the virile crayfish, originally misidentified as the spiny-cheek crayfish (Holdich and Black, 2007), was reported also from a pond in the catchment of the River Lee in north London. These were locally reported to have occurred as the result of a local resident disposing of his collection of exotic aquarium pets. Further populations of virile crayfish were later recorded in adjacent watercourses within a $7 \mathrm{~km}$ radius of the suspected point of introduction in England, suggesting a dispersal rate of more than $2 \mathrm{~km} \cdot \mathrm{yr}^{-1}$ (Ahern et al., 2008). Particularly downstream spread in the Lee Navigation and connecting streams and ditches can be expected (Holdich et al., 2009). Genetic data suggest that the original source was the same for both Dutch and English populations (Filipová et al., 2010) but it remains unclear when their introduction pathways diverged.

The virile crayfish is most likely responsible for the decline of macrophytes in a few canals in the Netherlands (Soes and Koese, 2010 and reference therein) but further studies confirming and quantifying its impacts on European ecosystems are lacking. There are numerous features reported for virile crayfish suggesting that this taxon may become an invader with substantial impact: early maturation, relatively high fecundity, short incubation and fast growth 


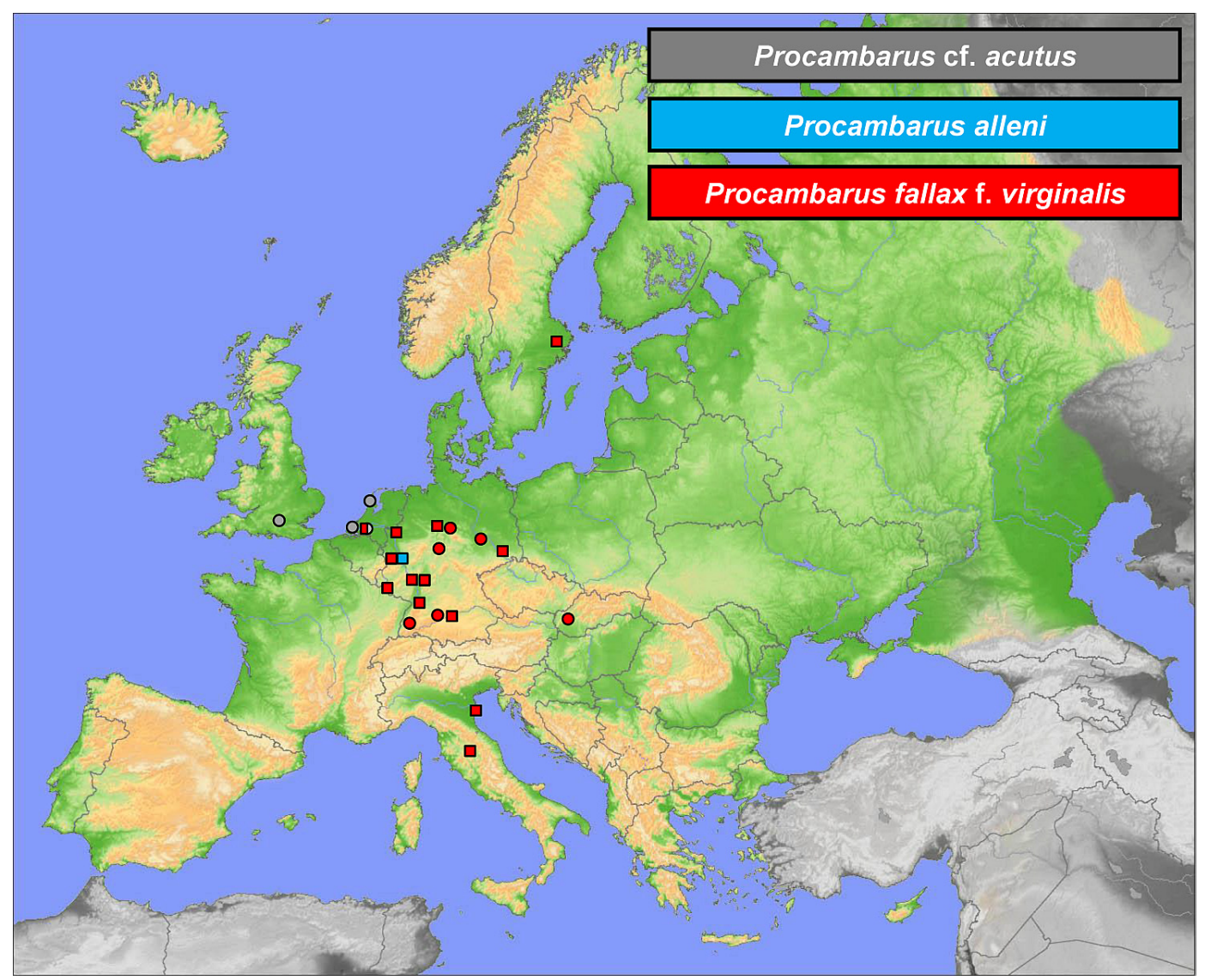

\section{Figure 10}

Distribution of the New NICS (Procambarus spp.) in Europe. Circles indicate established populations, squares one-time findings or populations of an unclear status.

(Momot, 1967; Weagle and Ozburn, 1972; Corey, 1987), high aggressiveness (Bovbjerg, 1970), extensive burrowing activity (Hazlett et al., 1974; Hazlett and Rittschof, 1985), and ability to withstand low temperatures (Williams et al., 2011). Indeed, virile crayfish showed the potential to rapidly invade new waterbodies and outcompete native congeners in North America (Phillips et al., 2009; Swecker et al., 2010). However, it should be kept in mind that individual studies may refer to different lineages of the species complex, thus the performance of the one living in European waters should be evaluated in detail.

\section{> PROCAMBARUS CF. ACUTUS; WHITE RIVER CRAYFISH (FIGURE 10)}

Similarly to previously mentioned species, taxonomy of European populations identified as the white river crayfish, Procambarus acutus, is not entirely clear. Its first established population was recorded in the Netherlands in 2005 (Soes and van Eekelen, 2006). However, genetic analyses of Dutch specimens revealed the coexistence of two divergent mitochondrial lineages, one assigned to $P$. acutus and another matching to reference samples identified as southern white river crayfish, $P$. zonangulus (Filipová et al., 2011), a species considered closely related to $P$. acutus (Hobbs and Hobbs, 1990). Initial results suggested that one of the lineages strongly dominates but analysis of additional specimens confirmed that both are common. The taxonomic status and interactions of these two coexisting lineages in Dutch waters require clarification. As the taxonomy of the whole $P$. acutus complex apparently needs revision (Crandall, 2010a, 2010b; Filipová et al., 2011), we at present refer to European populations of white river crayfish as Procambarus cf. acutus. 
Distribution of Dutch populations was recently summarized in Koese and Soes (2011). Recently, self-sustaining population of white river crayfish was found also in southeastern England (Reading, Berkshire; Almeida et al., 2013). Besides these two recently established populations, introduction of white river crayfish from Louisiana to Spain along with $P$. clarkii in the 1970s was also suggested (Habsburgo-Lorena, 1979; Henttonen and Huner, 1999). However, that introduction was successful only in case of the red swamp crayfish.

\section{> PROCAMBARUS FALLAX F. VIRGINALIS; MARBLED CRAYFISH (FIGURE 10)}

Marbled crayfish, also known under the German name Marmorkrebs, has spread in German and Austrian pet shops since the mid-1990s (Lukhaup, 2001). Besides its attractive marbled coloration and undemanding nature, it became a popular pet due to its obligately asexual reproduction. The reproductive mode of marbled crayfish, later identified as apomictic parthenogenesis (Martin et al., 2007), allows a single female to establish a viable population not only in aquarium conditions but in principle also in the wild. These exclusively female aquarium stocks, for several years of unclear taxonomic position, were confirmed to belong to the slough crayfish Procambarus fallax (Martin et al., 2010), an American species occurring in Florida and Georgia (Taylor et al., 2007). In its native range, however, all-female populations have never been found. The parthenogenetic marbled crayfish was thus formally described as $P$. fallax f. virginalis (Martin et al., 2010).

Marbled crayfish became soon widely distributed among hobbyists, and are frequently available in pet shops. Its fast growth, high fecundity, frequent spawning, short embryogenesis and early maturation (Seitz et al., 2005) often results in fast overpopulating of aquaria. This leads not only to providing excess animals to other aquarium hobbyists and pet shops but unfortunately also to apparently frequent releases to natural habitats (Holdich et al. 2009; Chucholl et al. 2012).

The first European specimen of marbled crayfish found in the wild was caught in Germany in 2003 (Marten et al. 2004). A few specimens were found crawling on the land after the cleaning of a canal in the Netherlands in 2004 (Soes and van Eekelen, 2006) and a single specimen of marbled crayfish was reported in a well-established population of the red swamp crayfish in a slow flowing canal in Tuscany, central Italy in 2008 (Marzano et al., 2009). Further records of isolated specimens were meanwhile reported from Germany. The situation dramatically changed in 2010, when established populations were found not only in Germany but also in Slovakia (Janský a Mutkovič, 2010; see Chucholl et al., 2012 for review), and additional findings in Germany followed. Since the overview by Chucholl et al. (2012), at least three further records are reported from Germany, some of which may represent established populations (C. Chucholl, pers. comm.). Self-sustaining population was also suggested to occur close to Venice, Italy (Z. Ďuriš, pers. comm.).

Recently, another alarming report came from Sweden where 13 specimens of marbled crayfish were found in December 2012 in the River Märstaån in the central part of country (Bohman et al., 2013). Later attempts to confirm the presence of this species failed, so it is not known whether it can establish reproducing population under Scandinavian climatic conditions. Further potential occurrence of marbled crayfish was also suggested close to Skara, southern Sweden (Bohman et al., 2013). However, although the photographs of the respective animals are of low quality and lack essential details, we believe they actually do not represent this taxon. Further attempts to confirm its occurrence were also unsuccessful (L. Edsman, pers. comm.).

\section{> PROCAMBARUS ALLENI; FLORIDA CRAYFISH (FIGURE 10)}

Procambarus alleni, labelled also Everglade crayfish or electric blue crayfish, is a species widely available in aquarium trade (Chucholl, 2013), popular for its blue colouration. Report 
on $P$. alleni in France has been mentioned by Holdich et al. (2006) but no details were provided. Gross (2013) recently described capture of a large single male $P$. alleni in the Rhine (Germany) in March 2013. This record is likely another of the series of accidental findings of crayfish released from aquaria without establishing a viable population. However, it demonstrates that aquarium pet trade and related animal escapes, and especially intentional releases by hobbyists, represent a serious problem. Procambarus alleni, in particular, is a likely candidate for future releases, as it is relatively big and widespread in German aquarium trade. In addition, it is one of the species classified as high-risk by Chucholl (2013), based on the data on biogeography, introduction history, biology, and ecology of the species.

\section{CONCLUSIONS}

Our review summarizes not only improvements in knowledge on crayfish distribution in many European regions but points out the ongoing changes related to spread and releases of alien species. Further expansion of already established Old NICS seems inevitable in already colonized regions. Unfortunately, it seems unlikely that the trend of uncovering new established populations and even additional species of New NICS will cease. Most species available frequently in German aquarium trade and evaluated by Chucholl (2013) as high-risk have already been found in European open waters, either as established populations (e.g., P. clarkii, P. fallax f. virginalis, $C$. destructor) or as accidental findings $(P$. alleni). The last remaining species classified as high-risk is Orconectes neglectus, not yet reported from the wild in Europe. However, with at least $120 \mathrm{NICS}$ available for sale, there is a substantial potential for additional species being released. Analyses of social, economic and demographic factors point out that more NICS are present in European countries with higher human population density and gross domestic product per capita (Perdikaris et al., 2012), which likely corresponds with developed pet trade and higher NICS availability.

Despite numerous recent advances that allowed updating our distribution maps for crayfish species in Europe, we are aware that the real situation in many regions may substantially differ from that on the maps. In particular, some of the largest countries are probably not faithfully represented. Scattered information is available from Germany and Spain, resolution is insufficient for France, and recent updates are lacking from Poland. Such situation will hopefully improve as better-quality data are collected by appropriate national bodies and made available to scientific community and other stakeholders. Keeping distribution maps up-to-date would be a never-ending task. However, we believe that even an incomplete update will be of use for the astacological community.

\section{ACKNOWLEDGEMENTS}

We are grateful to all the following colleagues who provided information on crayfish distribution: Leopold Füreder, Manfred Pöckl, Martin Schletterer \& Martin Weinländer (Austria), Anatoly V. Alekhnovich, Victor F. Kulesh, Vladimir Razlutskij \& Vitaliy Semenchenko (Belarus), Pieter Boets \& Roger Cammaerts (Belgium), Ivan Botev, Emilian Stoynov, Milcho Todorov \& Angel Zaikov (Bulgaria), Goran Klobučar \& Ivana Maguire (Croatia), Christos loakeimidis (Cyprus), Zdeněk Ďuriš, Lenka Filipová, Lukáš Jurek, Eva Kozubíková-Balcarová \& Tomáš Policar (Czech Republic), Søren Berg and Christian Skov (Denmark), Margo Hurt \& Tiit Paaver (Estonia), Japo Jussila \& Markku Pursiainen (Finland), Marc Collas, Frédéric Grandjean \& Catherine Souty-Grosset (France), Christoph Chucholl, Andreas Müller-Belecke \& Peer Martin (Germany), Manos Koutrakis \& Costas Perdikaris (Greece), Dénes Gál, Károly Györe, Vilmos Józsa \& Miklós Puky (Hungary), Laura Aquiloni, Silvia Bertocchi, Francesca Gherardi \& Elena Tricarico (Italy), Julian Reynolds (Ireland), Inese Briede \& Natalja Grudule (Latvia), Kestutis Arbačiauskas (Lithuania), Menno Soes (Netherlands), Stein Ivar Johnsen (Norway), Joanna Jaszczołt (Poland), Joao Manuel Bernardo \& Ronaldo Sousa (Portugal), Lucian Pârvulescu (Romania), Olga Mitskevich, Olga Susloparova, Aleksey Tamulyonis \& Vladimir Borisovich 
Ushivtsev (Russia), Eduard Stloukal (Slovakia), Martina Jaklič \& Al Vrezec (Slovenia), Alvaro Antón, Fernando Alonso, Javier Diéguez-Uribeondo, Alexandre Mestre \& Iván Vedia (Spain), Patrik Bohman \& Lennart Edsman (Sweden), Daniel Hefti (Switzerand), Muzaffer Harlioğlu (Turkey), Joanna James, David M. Holdich \& Stephanie Peay (UK), Alexander Tertyshny (Ukraine). Petr J. Juračka created most of the colourful distribution maps. Finally, we thank three anonymous referees for their input. The Czech Science Foundation supported this work through the project P505/12/0545. Partial funding was also provided by projects CENAKVA (CZ.1.05/2.1.00/01.0024) and CENAKVA II (project LO1205 with a financial support from the Ministry of Education, Youth, and Sports of the Czech Republic under the NPU I program).

\section{REFERENCES}

Ahern D., England J. and Ellis A., 2008. The virile crayfish, Orconectes virilis (Hagen, 1870) (Crustacea: Decapoda: Cambaridae), identified in the UK. Aquat. Invasions, 3, 102-104.

Aklehnovich A. and Razlutskij V., 2013. Distribution and spread of spiny-cheek crayfish Orconectes limosus (Rafinesque, 1817) in Belarus. Biolnvasions Rec., 2, 221-225.

Alderman D.J., 1996. Geographical spread of bacterial and fungal diseases of crustaceans. Rev. sci. tech. Off. Int. Epiz., 15, 603-632.

Almeida D., Ellis A., England J. and Copp G.H., 2013. Time-series analysis of native and non-native crayfish dynamics in the Thames River Basin (south-eastern England). Aquat. Conserv., DOI: 10.1002/aqc.2366.

Aquiloni L., Tricarico E. and Gherardi F., 2010. Crayfish in Italy: distribution, threats and management. Int. Aquat. Res., 2, 1-14.

Arbačiauskas K., Višinskienè G., Smilgevičienè S. and Rakauskas V., 2011a. Non-indigenous macroinvertebrate species in Lithuanian fresh waters, Part 1: Distributions, dispersal and future. Knowl. Managt. Aquat. Ecosyst., 402, 12.

Arbačiauskas K., Višinskienè G. and Smilgevičienè S., 2011b. Non-indigenous macroinvertebrate species in Lithuanian fresh waters, Part 2: Macroinvertebrate assemblage deviation from naturalness in lotic systems and the consequent potential impacts on ecological quality assessment. Knowl. Managt. Aquat. Ecosyst., 402, 13.

Benejam L., Saura-Mas S. and Saperas A., 2011. First record of the spiny-cheek crayfish Orconectes limosus (Rafinesque, 1817) introduced to the Iberian Peninsula. Aquat. Invasions, 6 (Suppl. 1), S111-S113.

Beroiz B., Callejas C., Alonso F. and Ochando M.D., 2008. Genetic structure of Spanish white-clawed crayfish (Austropotamobius pallipes) populations as determined by RAPD analysis: reasons for optimism. Aquat. Conserv., 18, 190-201.

Bódis E., Borza P., Potyó I., Puky M., Weiperth A. and Guti G., 2012. Invasive mollusc, crustacean, fish and reptile species along the Hungarian stretch of the river Danube and some connected waters. Acta Zool. Acad. Sci. Hung., 58 (Suppl.), 29-45.

Boets P., Lock K., Adriaens T., Mouton A. and Goethals P.L., 2012. Distribution of crayfish (Decapoda, Astacoidea) in Flanders (Belgium): an update. Belg. J. Zool., 142, 86-92.

Bohman P., Edsman L. and Nordwall F., 2006. The effect of the large-scale introduction of signal crayfish on the spread of crayfish plague in Sweden. Bull. Fr. Pêche Piscic., 380-381, 1291-1302.

Bohman P., Edsman L., Martin P. and Scholtz G., 2013. The first Marmorkrebs (Decapoda: Astacida: Cambaridae) in Scandinavia. Biolnvasions Rec., 2, 227-232.

Bolea L., 1996. Primera cita de Cherax destructor (Crustacea: Decapoda: Parastacidae) en Europa. Bol. Soc. Entomol. Aragonesa (Zaragoza), 14, 49-51.

Bovbjerg R.V., 1970. Ecological isolation and competitive exclusion in two crayfish (Orconectes virilis and Orconectes immunis). Ecology, 51, 225-236.

Briede I., 2011. Crayfish in Latvia. Acta Biol. Univ. Daugavpiliensis, 11, 83-87.

Capurro M., Galli L., Mori M., Salvidio S. and Arillo A., 2007. The signal crayfish, Pacifastacus leniusculus (Dana, 1852) [Crustacea: Decapoda: Astacidae], in the Brugneto Lake (Liguria, NW Italy). The beginning of the invasion in the River Po watershed. Aquat. Invasions, 2, 17-24. 
CEP, 2009. The Caspian Environment Programme, available at http://www.caspianenvironment.org/ newsite/Caspian-Environmentallssues.htm.

Cherkashina N.Ya., 1999. Caspiastacus pachypus (Rathke, 1837), its biology and distribution. Freshw. Crayfish, 12, 846-853.

Chiesa S., Scalici M., Negrini R., Gibertini G. and Nonnis Marzano F., 2011. Fine-scale genetic structure, phylogeny and systematics of threatened crayfish species complex. Mol. Phylogenet. Evol., 61, $1-11$.

Chucholl C., 2009. The 'newcomer' Orconectes immunis keeps spreading in the upper Rhine plain. Crayfish News: IAA Newsletter, 31(3), 4-5.

Chucholl C., 2011. Population ecology of an alien "warm water" crayfish (Procambarus clarkii) in a new cold habitat. Knowl. Managt. Aquat. Ecosyst., 401, 29.

Chucholl C., 2012. Understanding invasion success: life-history traits and feeding habits of the alien crayfish Orconectes immunis (Decapoda, Astacida, Cambaridae). Knowl. Managt. Aquat. Ecosyst., 404, 4.

Chucholl C., 2013. Invaders for sale: trade and determinants of introduction of ornamental freshwater crayfish. Biol. Invasions, 15, 125-141.

Chucholl C. and Daudey T., 2008. First record of Orconectes juvenilis (Hagen 1870) in eastern France: update to the species identity of a recently introduced orconectid crayfish (Crustacea: Astacida). Aquat. Invasions, 3, 105-107.

Chucholl C., Stich H.B. and Maier G., 2008. Aggressive interactions and competition for shelter between a recently introduced and an established invasive crayfish: Orconectes immunis vs. O. limosus. Fund. Appl. Limnol., 172, 27-36.

Chucholl C., Morawetz K. and Groß H., 2012. The clones are coming-strong increase in Marmorkrebs [Procambarus fallax (Hagen, 1870) f. virginalis] records from Europe. Aquat. Invasions, 7, 511-519.

Collas M., Julien C. and Monnier D., 2007. La situation en France. Résultats des enquêtes nationales réalisées entre 1877 et 2006 par le Conseil Supérieur de la Pêche [Situation of the crayfish in France. Results of the national surveys performed between 1977 and 2006 by the Conseil Supérieur de la Pêche (CSP)]. Bull. Fr. Pêche Piscic., 386, 1-38. [In French, English summary]

Collas M., Beinsteiner D., Fritsch S., Morelle S. and L'Hospitalier M., 2011. Première observation en France de l'Ecrevisse calicot, Orconectes immunis (Hagen, 1870) [First observation of the calico crayfish Orconectes immunis (Hagen, 1870) in France]. Ann. Sci. Rés. Bios. Trans. Vosges du Nord-Pfälzerwald, 16, 18-36. [in French, English and German summary]

Corey S., 1987. Comparative fecundity of four species of crayfish in southwestern Ontario, Canada (Decapoda, Astacidae). Crustaceana, 52, 276-286.

Crandall K.A., 2010a. Procambarus acutus. In: IUCN 2011. IUCN Red List of Threatened Species. Version 2011.1, available at http://www.iucnredlist.org/details/154022/0.

Crandall K.A., 2010b. Procambarus zonangulus. In: IUCN 2011. IUCN Red List of Threatened Species. Version 2011.1, available at http://www.iucnredlist.org/details/153993/0.

Creed R.P. and Reed J.M., 2004. Ecosystem engineering by crayfish in a headwater stream community. J. N. Am. Benthol. Soc., 23, 224-236.

Cukerzis J., 1979. On acclimatization of Pacifastacus leniusculus Dana in an isolated lake. Freshw. Crayfish, 4, 445-450.

D'Agaro E., De Luise G. and Lanari D., 1999. The current status of crayfish farming in Italy. Freshw. Crayfish, 12, 506-517.

Dehus P., Dussling U. and Hoffmann C., 1999. Notes on the occurrence of the calico crayfish (Orconectes immunis) in Germany. Freshw. Crayfish, 12, 786-790.

Diéguez-Uribeondo J., Royo F., Souty-Grosset C., Ropiquet A. and Grandjean F., 2008. Low genetic avariability of the white-clawed crayfish in the Iberian Peninsula: its origin and management implications. Aquat. Conserv., 18, 19-31.

Dorn N.J. and Wojdak J.M., 2004. The role of omnivorous crayfish in littoral communities. Oecologia, 140, 150-159.

Edgerton B.F., Henttonen P., Jussila J., Mannonen A., Paasonen P., Taugbøl T., Edsman L. and SoutyGrosset C., 2004. Understanding the causes of disease in European freshwater crayfish. Conserv. Biol., 18, 1466-1474. 
Edwards B.A., Jackson D.A. and Somers K.M., 2009. Multispecies crayfish declines in lakes: implications for species distributions and richness. J. N. Am. Benthol. Soc., 28, 719-732.

Ellis A., Jackson M.C., Jennings I., England J. and Phillips R., 2012. Present distribution and future spread of Louisiana red swamp crayfish Procambarus clarkii (Crustacea, Decapoda, Astacida, Cambaridae) in Britain: Implications for conservation of native species and habitats. Knowl. Managt. Aquat. Ecosyst., 406, 5.

Ferincz A., Kováts N., Benkö-Kiss A. and Paulovits G., 2014. New record of the spiny-cheek crayfish, Orconectes limosus (Rafinesque, 1817) in the catchment of Lake Balaton (Hungary). Biolnvasions Rec., 3, 35-38.

Filipová L., Holdich D.M., Lesobre J., Grandjean F. and Petrusek A., 2010. Cryptic diversity within the invasive virile crayfish Orconectes virilis (Hagen, 1870) species complex: new lineages recorded in both native and introduced ranges. Biol. Invasions, 12, 983-989.

Filipová L., Grandjean F., Chucholl C., Soes D.M. and Petrusek A., 2011. Identification of exotic North American crayfish in Europe by DNA barcoding. Knowl. Managt. Aquat. Ecosyst., 401, 11.

Filipová L., Petrusek A., Matasová K., Delaunay C. and Grandjean F., 2013. Prevalence of the crayfish plague pathogen Aphanomyces astaci in populations of the signal crayfish Pacifastacus leniusculus in France: evaluating the threat to native crayfish. PLOS ONE, 8, e70157.

Fratini S., Zaccara S., Barbaresi S., Grandjean F., Souty-Grosset C., Crosa G. and Gherardi F., 2005. Phylogeography of the threatened crayfish (genus Austropotamobius) in Italy: implications for its taxonomy and conservation. Heredity, 94, 108-118.

Füreder, L. (ed.), 2009. Flusskrebse. Biologie - Ökologie - Gefahrdung. Veröffentlichungen Naturmus. Südtirol, 6, $144 \mathrm{p}$.

Füreder L., Edsman L., Holdich D., Kozák P., Machino Y., Pöckl M., Renai B., Reynolds J., Schulz H., Schulz R., Sint D., Taugbøl T. and Trouilhé M.C., 2006. Indigenous crayfish - habitat and threats. In: Souty-Grosset C., Holdich D.M., Noël P.Y., Reynolds J.D. and Haffner P. (eds.), Atlas of Crayfish in Europe, Muséum national d'Histoire naturelle, Paris, Patrimoines naturels, 64, $26-47$.

Gelmar C., Pätzold F., Grabow K. and Martens A., 2006. Der Kalikokrebs Orconectes immunis am nördlichen Oberrhein: ein neuer amerikanischer Flusskrebses breitet sich rasch in Mitteleuropa aus (Crustacea: Cambaridae). Lauterbornia, 56, 15-25.

Gherardi F., Aquiloni L., Diéguez-Uribeondo J. and Tricarico E., 2011. Managing invasive crayfish: is there a hope? Aquat. Sci., 73, 185-200.

Gouin N., Grandjean F., Bouchon D., Reynolds J.D. and Souty-Grosset C., 2001. Population genetic structure of the endangered freshwater crayfish Austropotamobius pallipes, assessed using RAPD markers. Heredity, 87, 80-87.

Gouin N., Grandjean F., Pain S., Souty-Grosset C. and Reynolds J., 2003. Origin and colonization history of the white-clawed crayfish, Austropotamobius pallipes, in Ireland. Heredity, 91, 70-77.

Grandjean F., 2012. Bilan génétique des populations d'écrevisses autochtones de Haute-Savoie [Genetic assessment of indigenous crayfish populations in Haute-Savoie]. Report for Fédération de pêche de la Haute-Savoie, available at http://www.pechehautesavoie.com/wp-content/ uploads/2012/01/Bilan_genetique_des_populations_decrevisses_autochtones_de_Haute_ Savoie.pdf.

Grandjean F., Souty-Grosset C., Raimond R. and Holdich D.M., 1997. Geographical variation of mitochondrial DNA between populations of the white-clawed crayfish Austropotamobius pallipes. Freshw. Biol., 37, 493-501.

Grandjean F., Gouin N., Souty-Grosset C. and Diéguez-Uribeondo J., 2001. Drastic bottlenecks in the endangered crayfish species Austropotamobius pallipes in Spain and implications for its colonization history. Heredity, 86, 431-438.

Grandjean F., Frelon-Raimond M. and Souty-Grosset C., 2002. Compilation of molecular data for the phylogeny of the genus Austropotamobius: one species or several? Bull. Fr. Pêche Piscic., 367, 671-680.

Gross H., 2013. Blauer Floridakrebs (Procambarus alleni) im Rhein! Forum Flusskrebse, 19, 33-35.

Groß H., Burk C. and Hill A., 2008. Die Flusskrebsfauna in NRW. Natur in NRW, 4, 52-56.

Györe K., Józsa V. and Gál D., 2013. The distribution of crayfish (Decapoda: Astacidae, Cambaridae) population in Cris and Mures rivers crossing the Romanian-Hungarian border. AACL Bioflux, 6 , $18-26$. 
Habsburgo-Lorena A.S., 1979. Present situation of exotic species of crayfish introduced into Spanish continental waters. Freshw. Crayfish, 4, 175-184.

Hazlett A.B. and Rittschof D., 1985. Variation in rate of growth in the crayfish Orconectes virilis. J. Crustacean Biol., 5, 341-346.

Hazlett B., Rittschof D. and Rubenstein D., 1974. Behavioral biology of the crayfish Orconectes virilis I. Home range. Am. Midl. Nat., 92, 301-319.

Henttonen P. and Huner J.V., 1999. The introduction of alien species of crayfish in Europe: A historical introduction. In: Gherardi F. and Holdich D.M. (eds.), Crayfish in Europe as alien species - how to make the best of a bad situation? A.A. Balkema, Rotterdam, 13-22.

Hobbs H.H., Jr. and Hobbs H.H., III., 1990. A new crayfish (Decapoda: Cambaridae) from southeastern Texas. Proc. Biol. Soc. Wash., 103, 608-613.

Holdich D. and Black J., 2007. The spiny-cheek crayfish, Orconectes limosus (Rafinesque, 1817) [Crustacea: Decapoda: Cambaridae], digs into the UK. Aquat. Invasions, 2, 1-16.

Holdich D.M., 2002. Distribution of crayfish in Europe and some adjoining countries. Bull. Fr. Pêche Piscic., 367, 611-650.

Holdich D.M. and Sibley P.J., 2009. ICS and NICS in Britain in the 2000s. In: Brickland J., Holdich D.M. and Imhoff E.M. (eds.), Crayfish Conservation in the British Isles, Proceedings of conference held in Leeds, 13-33.

Holdich D.M., Haffner P. and Noël P., 2006. Species files. In: Souty-Grosset C., Holdich D.M., Noël P.Y., Reynolds J.D. and Haffner P. (eds.), Atlas of Crayfish in Europe, Muséum national d'Histoire naturelle, Paris, Patrimoines naturels, 64, 50-129.

Holdich D.M., Reynolds J.D., Souty-Grosset C. and Sibley P. J., 2009. A review of the ever increasing threat to European crayfish from non-indigenous crayfish species. Knowl. Managt. Aquat. Ecosyst., 394-395, 11.

Holdich D.M., James J., Jackson C. and Peay S. 2014. The North American signal crayfish, with particular reference to its success as an invasive species in Great Britain. Ecol. Ethol. Evol., 26, in press.

Hudina S., Faller M., Lucić A., Klobučar G. and Maguire I., 2009. Distribution and dispersal of two invasive crayfish species in the Drava River basin, Croatia. Knowl. Managt. Aquat. Ecosyst., 394-395, 09.

Hudina S., Lucić A., Žganec K. and Janković S., 2011. Characteristics and movement patterns of a recently established invasive Pacifastacus leniusculus population in the river Mura, Croatia. Knowl. Managt. Aquat. Ecosyst., 403, 7.

Hudina S., Žganec K., Lucić A., Trgovčić K. and Maguire I., 2013. Recent invasion of the karstic river systems in Croatia through illegal introductions of the signal crayfish. Freshw. Crayfish, 19, 21-27.

Jaklič M. and Vrezec A., 2011. The first tropical alien crayfish species in European waters: the redclaw Cherax quadricarinatus (Von Martens, 1868) (Decapoda, Parastacidae). Crustaceana, 84, 5-6.

Janský V. and Kautman J., 2007. Americký rak Orconectes limosus (Crustacea: Decapoda: Cambaridae) už aj na Slovensku [North American spiny-cheek crayfish Orconectes limosus (Crustacea: Decapoda: Cambaridae) also in Slovakia]. Acta Rer. Natur. Mus. Nat. Slov., 53, 21-25. [in Slovak, English summary]

Janský V. and Mutkovič A., 2010. Rak Procambarus sp. (Crustacea: Decapoda: Cambaridae) - první nález na Slovensku [Marbled crayfish - Procambarus sp. (Crustacea: Decapoda: Cambaridae) first find in Slovakia]. Acta Rer. Natur. Mus. Nat. Slov., 56, 64-67. [in Slovak, English summary]

Johnsen S.I., Taugbøl T., Andersen O., Museth J. and Vrålstad T., 2007. The first record of the nonindigenous signal crayfish Pacifastacus leniusculus in Norway. Biol. Invasions, 9, 939-941.

Klobučar G.I.V., Podnar M., Jelić M., Franjeviæ D., Faller M., Štambuk A., Gottstein S., Simić V. and Maguire I., 2013. Role of the Dinaric Karst (western Balkans) in shaping the phylogeographic structure of the threatened crayfish Austropotamobius torrentium. Freshw. Biol., 58, 1089-1105.

Koese B. and Soes M., 2011. De Nederlandse rivierkreeften (Astacoidea \& Parastacoidea). Entomologische Tabellen, 6, $107 \mathrm{p}$.

Kokko H., Koistinen L., Harlioğlu M.M., Makkonen J., Aydın H. and Jussila J., 2012. Recovering Turkish narrow clawed crayfish (Astacus leptodactylus) populations carry Aphanomyces astaci. Knowl. Managt. Aquat. Ecosyst., 404, 12. 
Korshenko A. and Gul A.G., 2005. Pollution of the Caspian Sea. In: Kostianoy A.G. and Kosarev A.N. (eds.), The Caspian Sea Environment, Springer, Berlin \& Heidelberg, 109-142.

Kostyuk V.S., Garbar A.V. and Mezhzherin S.V., 2013. Karyotypes and morphological variability of crayfish Pontastacus leptodactylus and P. angulosus (Malacostraca, Decapoda). Ves. Zool., 47, 11-16.

Koutrakis E., Perdikaris C., Machino Y., Savvidis G. and Margaris N., 2007. Distribution, recent mortalities and conservation measures of crayfish in Hellenic fresh waters. Bull. Fr. Pêche Piscic., 385, 25-44.

Kozák P., Ďuriš Z., Petrusek A., Buřič M., Horká I., Kouba A., Kozubíková E., Policar T., 2013. Biologie a chov raků [Biology and culture of crayfish], Faculty of Fisheries and Protection of Waters, University of South Bohemia in České Budějovice, $418 \mathrm{p}$.

Kozubíková E., Petrusek A., Ďuriš Z, Martín M.P., Diéguez-Uribeondo J. and Oidtmann B., 2008. The old menace is back: Recent crayfish plague outbreaks in the Czech Republic. Aquaculture, 274, 208-217.

Kozubíková E., Vrålstad T., Filipová L. and Petrusek A., 2011. Re-examination of the prevalence of Aphanomyces astaci in North American crayfish populations in Central Europe by TaqMan MGB real-time PCR. Dis. Aquat. Org., 97, 113-125.

Lipták B., Vitázková B. and Stloukal., 2013. First record of the spinycheek crayfish (Orconectes limosus) in the Serbo-Romanian Tamiš River. Freshw. Crayfish, 19, 229-232.

Lodge D.M., Deines A., Gherardi F., Yeo D.C., Arcella T., Baldridge A.K., Barnes M.A., Chadderton W.L., Feder J.L., Gantz C.A., Howard G.W., Jerde C.L., Peters B.W., Peters J.A., Sargent L.W., Turner C.R., Wittmann M.E. and Zeng Y., 2012. Global introductions of crayfishes: evaluating the impact of species invasions on ecosystem services. Annu. Rev. Ecol. Evol. Syst., 43, 449-472.

Lukhaup C., 2001. Procambarus sp. The Marbled crayfish. Aquaristik Aktuell, 7-8, 48-51.

Machino Y. and Holdich D.M., 2006. Distribution of crayfish in Europe and adjacent countries: updates and comments. Freshw. Crayfish, 15, 292-323.

Maguire I. and Gottstein-Matočec S., 2004. The distribution pattern of freshwater crayfish in Croatia. Crustaceana, 77, 25-47.

Maguire I. and Dakić L., 2011. Comparative analyses of Astacus leptodactylus morphological characteristics from Croatia and Armenia. Biologia, 66, 491-498.

Maguire I., Klobučar G., Marčić Z. and Zanella D., 2008. The first record of Pacifastacus leniusculus in Croatia. Crayfish News, 30(4), 4.

Maguire I., Jelić M. and Klobučar G., 2011. Update on the distribution of freshwater crayfish in Croatia. Knowl. Managt. Aquat. Ecosyst., 401, 31.

Maguire I., Podnar M., Schrimpf A. and Schulz, H., 2014. Two distinct evolutionary lineages of the Astacus leptodactylus species complex (Decapoda: Astacidae) inferred by phylogenetic analyses. Invertebr. Syst., DOI: 10.1071/IS13030.

Marino F., Pretto T., Tosi F., Monaco S., De Stefano C., Manfrin A. and Quaglio F., 2014. Mass mortality of Cherax quadricarinatus (von Martens, 1868) reared in Sicily (Italy): crayfish plague introduced in an intensive farming. Freshw. Crayfish, 20, in press.

Marten M., Werth C. and Marten D., 2004. Der Marmorkrebs (Cambaridae, Decapoda) in Deutschland ein weiteres Neozoon im Einzugsgebiet des Rheins. Lauterbornia, 50, 17-23.

Martin P., Kohlmann K. and Scholtz G., 2007. The parthenogenetic Marmorkrebs (marbled crayfish) produces genetically uniform offspring. Naturwissenschaften, 94, 843-846.

Martin P., Pfeifer M. and Füllner G., 2008a. First record of the stone crayfish Austropotamobius torrentium (Schrank, 1803) (Crustacea: Decapoda: Astacidae) from Saxony (Germany). Faun. Abhandl. (Dresden), 26, 103-108.

Martin P., Pfeifer M. and Füllner G., 2008b. Flusskrebse in Sachsen. Sächsisches Landesamt für Umwelt, Landwirtschaft und Geologie, Dresden, 85 p.

Martin P., Dorn N., Kawai T., van der Heiden C. and Scholtz G., 2010. The enigmatic Marmorkrebs (marbled crayfish) is the parthenogenetic form of Procambarus fallax (Hagen, 1870). Contrib. Zool., 79, 107-118.

Marzano F.N., Scalici M., Chiesa S., Gherardi F., Piccinini A. and Gilbertini G., 2009. The first record of the marbled crayfish adds further threats to freshwaters in Italy. Aquat. Invasions, 4, 401-404.

Matallanas B., Ochando M.D., Vivero A., Beroiz B., Alonso F. and Callejas C., 2011. Mitochondrial DNA variability in Spanish populations of $A$. italicus inferred from the analysis of a COI region. Knowl. Managt. Aquat. Ecosyst., 401, 30. 
Matallanas B., Ochando M.D., Alonso F. and Callejas C., 2013. Phylogeography of the white-clawed crayfish (Austropotamobius italicus) in Spain: inferences from microsatellite markers. Mol. Biol. Rep., 40, 5327-5338.

Mathews L.M. and Warren A.H., 2008. A new crayfish of the genus Orconectes Cope, 1872 from southern New England (Crustacea: Decapoda: Cambariidae). Proc. Biol. Soc. Wash., 121, 374-381.

Mathews L.M., Adams L., Anderson E., Basile M., Gottardi E. and Buckholt M.A., 2008. Genetic and morphological evidence for substantial hidden biodiversity in a freshwater crayfish species complex. Mol. Phylogenet. Evol., 48, 126-135.

Momot W.T., 1967. Population dynamics and productivity of the crayfish Orconectes virilis in a marl lake. Am. Midl. Nat., 78, 55-81.

Momot W.T., 1995. Redefining the role of crayfish in aquatic ecosystems. Rev. Fisher. Sci., 3, 33-63.

Natural England, 2013. Standing advice species sheet: white-clawed crayfish, available at http://www. naturalengland.org.uk/Images/Crayfish_tcm6-21618.pdf.

NPWS, 2013. The status of EU protected habitats and species in Ireland. Species assessments volume 3, version 1.0. Unpublished report, National Parks \& Wildlife Services. Department of Arts, Heritage and the Gaeltacht, Dublin, Ireland, $713 \mathrm{p}$.

Oscoz J., Tomás, P. and Durán C., 2010. Review and new records of non-indigenous freshwater invertebrates in the Ebro River basin (Northeast Spain). Aquat. Invasions, 5, 263-284.

Ottburg F.G.W.A. and Roessink I., 2012. Europese rivierkreeften in Nederland: vaststellen, veiligstellen, versterken en veilige leefgebieden. [Noble crayfish in The Netherlands: Sample, Safeguard, Strengthen, Safety]. Alterra Report 2341, Wageningen University and Research Centre, Wageningen, $42 \mathrm{p}$.

Paaver T. and Hurt M., 2009. Status and management of noble crayfish Astacus astacus in Estonia. Knowl. Managt. Aquat. Ecosyst., 394-395, 18.

Pârvulescu L. and Zaharia C., 2012. Current limitations of the stone crayfish distribution in Romania: implications for its conservation status. Limnologica, 43, 143-150.

Pârvulescu L. and Zaharia C., 2014. Distribution and ecological preferences of noble crayfish in the Carpathian Danube basin: biogeographical insights into the species history. Hydrobiologia, 726, 53-63.

Pârvulescu L., Palos, C. and Molnar P., 2009. First record of the spiny-cheek crayfish Orconectes limosus (Rafinesque, 1817) (Crustacea: Decapoda: Cambaridae) in Romania. North-West J. Zool., 5, 424-428.

Pârvulescu L., Schrimpf A., Kozubíková E., Cabanillas Resino S., Vrålstad T., Petrusek A. and Schulz R., 2012. Invasive crayfish and crayfish plague on the move: first detection of the plague agent Aphanomyces astaci in the Romanian Danube. Dis. Aquat. Org., 98, 85-94.

Pârvulescu L., Zaharia C., Satmari A. and Drâgut, L., 2013. Is the distribution pattern of the stone crayfish in the Carpathians related to karstic refugia from Pleistocene glaciations? Freshw. Sci., 32, 1410-1419.

Pedraza-Lara C., Alda F., Carranza S. and Doadrio I., 2010. Mitochondrial DNA structure of the lberian populations of the white-clawed crayfish, Austropotamobius italicus italicus (Faxon, 1914). Mol. Phylogenet. Evol., 57, 327-342.

Perdikaris C., Kozák P., Kouba A., Konstantinidis E. and Paschos I., 2012. Socio-economic drivers and non-indigenous freshwater crayfish species in Europe. Knowl. Managt. Aquat. Ecosyst., 404, 1.

Pešek P., 2013. Genetic diversity of stone crayfish Austropotamobius torrentium in marginal areas of its distribution. MSc. thesis, Faculty of Science, Charles University in Prague, 57 p. [in Czech, English summary]

Petrusek A. and Petrusková T., 2007. Invasive American crayfish Pacifastacus leniusculus (Decapoda: Astacidae) in the Morava River (Slovakia). Biologia, 62, 356-359.

Phillips I.D., Vinebrooke R.D. and Turner M.A., 2009. Ecosystem consequences of potential range expansions of Orconectes virilis and Orconectes rusticus crayfish in Canada - a review. Environ. Rev., 17, 235-248,

Policar T. and Kozák P., 2000. Výskyt raků v ČR [Occurrence of the crayfish in the Czech Republic]. Bulletin VÚRH Vodňany, 36, 18-22. [in Czech, English summary]

Pursiainen M. and Mattila J., 2012. Rapujen levinneisyys ja tuotanto Suomessa 2010 [Distribution and production of crayfish in Finland 2010]. Riista- ja kalatalous - Tutkimuksia ja selvityksiä - [Game and Fisheries - Research and reports] 8/2012, 37 p. [in Finish] 
Rakauskas V., Ruginis T. and Arbačiauskas K., 2010. Expansion of the spinycheek crayfish, Orconectes limosus (Rafinesque 1817), in the Nemunas River basin, Lithuania. Freshw. Crayfish, 17, 73-76.

Reynolds J.D., 1988. Crayfish extinctions and crayfish plague in central Ireland. Biol. Conserv., 45, 279-285.

Rogers D. and Watson E. 2011a. Distribution database for crayfish in England and Wales. In: Rees M., Nightingale J. and Holdich D.M. (eds.), Species Survival: Securing white-clawed crayfish in a changing environment. Proceedings of a conference held on 16th and 17th November 2010 in Bristol, UK, 14-22.

Rogers D. and Watson E. 2011b. Captive breeding and reintroduction of white-clawed crayfish on the River Lathkill, Derbyshire. In: Rees M., Nightingale J. and Holdich D.M. (eds.), Species Survival: Securing white-clawed crayfish in a changing environment. Proceedings of a conference held on 16th and 17th November 2010 in Bristol, UK, 141-152.

Rumyantsev B.D., 1974. Freshwater crayfish of the Volga - Caspian. Food Industry, Moscow, 84 p. [in Russian]

Sandodden R. and Johnsen S.I., 2010. Eradication of introduced signal crayfish Pacifastacus leniusculus using the pharmaceutical BETAMAX VET. Aquat. Invasions, 5, 75-81.

Santucci F., laconelli M., Andreani P., Cianchi R., Nascetti G. and Bullini L., 1997. Allozyme diversity of European freshwater crayfish of the genus Austropotamobius. Bull. Fr. Pêche Piscic., 347, 663-676.

Scalici M., Chiesa S., Gherardi F., Ruffini M., Gilbertini G. and Marzano F.N., 2009. The new threat to Italian inland waters from the alien crayfish "gang": the Australian Cherax destructor Clark, 1936. Hydrobiologia, 632, 341-345.

Schrimpf A., Pârvulescu L., Copilas-Ciocianu D., Petrusek, A. and Schulz R., 2012. Crayfish plague pathogen detected in the Danube Delta - a potential threat to freshwater biodiversity in southeastern Europe. Aquat. Invasions, 7, 503-510.

Schrimpf A., Chucholl C., Schmidt T. and Schulz R., 2013a. Crayfish plague agent detected in populations of the invasive North American crayfish Orconectes immunis (Hagen, 1870) in the Rhine River, Germany. Aquat. Invasions, 8, 103-109.

Schrimpf A., Theissinger K., Dahlem J., Maguire I., Pârvulescu L., Schulz H.K. and Schulz R., $2013 b$. Phylogeography of noble crayfish (Astacus astacus) reveals multiple refugia. Freshw. Biol., DOI: 10.1111/fwb.12302.

Seitz R., Vilpoux K., Hopp U., Harzsch S. and Maier G., 2005. Ontogeny of the Marmorkrebs (marbled crayfish): a parthenogenetic crayfish with unknown origin and phylogenetic position. J. Exp. Zool., 303, 393-405.

Simić V., Petrović A., Rajković M. and Paunović M., 2008. Crayfish of Serbia and Montenegro - the population status and the level of endangerment. Crustaceana, 81, 1153-1176.

Skov C., Aarestrup K., Sivebæk F., Pedersen S., Vrålstad T. and Berg S., 2011. Non-indigenous signal crayfish Pacifastacus leniusculus are now common in Danish streams: preliminary status for national distribution and protective actions. Biol. Invasions, 13, 1269-1274.

Śmietana P., Schulz H.K., Keszka S. and Schulz R., 2006. A proposal for accepting Pontastacus as a genus of European crayfish within the family Astacidae based on a revision of the west and east taxonomic literature. Bull. Fr. Pêche Piscic., 380-381, 1041-1052.

Soes D.M., 2008. Een vondst van de Australische roodklauwkreeft (Cherax quadricarinatus) in Nederland. [A finding of an Australian redclaw crayfish (Cherax quadricarinatus) in the Netherlands.] Kreeftennieuwsbrief, 2, 7-8.

Soes D.M. and van Eekelen R., 2006. Rivierkreeften een opruuend problem? De Levende Natuur, 107, 56-59.

Soes D.M. and Koese B., 2010. Invasive crayfish in the Netherlands: a preliminary risk analysis. Interim report, Bureau Waardenburg bv, Stichting European Invertebrate Survey - Nederland, Invasive Alien Species Team, Waardenburg, 69 p.

Sokolsky A., Ushivtsev V., Mikouiza A.S. and Kalmikov E., 1999. Influence of sea level fluctuations on wild crayfish populations in the Caspian Sea. Freshw. Crayfish, 12, 655-664.

Son M.O., Novitsky R.A. and Dyadichko V.G., 2013. Recent state and mechanisms of invasions of exotic decapods in Ukrainian rivers. Vest. Zool., 47, 59-64. 
Sousa R., Freitas F.E., Mota M., Nogueira A.J. and Antunes C., 2013. Invasive dynamics of the crayfish Procambarus clarkii (Girard, 1852) in the international section of the River Minho (NW of the Iberian Peninsula). Aquat. Conserv., 23, 656-666.

Souty-Grosset C., Holdich D.M., Noël P.Y., Reynolds J.D. and Haffner P. (eds.), 2006. Atlas of Crayfish in Europe, Muséum national d'Histoire naturelle, Paris. Patrimoines naturels, 64, 187 p.

Starobogatov Ya.I., 1995. Taxonomy and geographical distribution of crayfishes of Asia and East Europe (Crustacea Decapoda Astacoidei). Arthropoda Sel., 4-3, 3-25.

Stephanou D., 1987. Cyprus Country Report for 1986-1987, 3 p., available at http://www.fao.org/ docrep/005/s7360b/S7360B02.htm.

Stoynov E., Parvanov, D. and Grozdanov A., 2013. Distribution of crayfish and crabs in the upper reaches of the Kamchiya River, Bulgaria. Bulg. J. Agric. Sci., 19, 250-254.

Svoboda J., Kozubíková E., Kozák P., Kouba A., Bahadir Koca S., Diler Ö., Diler I., Policar T. and Petrusek, A. (2012). PCR detection of the crayfish plague pathogen in narrow-clawed crayfish inhabiting Lake Eğirdir Turkey. Dis. Aquat. Org., 98, 255-259.

Swecker C.D., Jones T.G., Donahue K. II, McKinney D. and Smith G.D., 2010. The extirpation of Orconectes limosus (Spinycheek crayfish) populations in West Virginia. Southeast. Nat., 9 (sp3), 155-164.

Taylor C.A., 2000. Systematic studies of the Orconectes juvenilis complex (Decapoda: Cambaridae), with descriptions of two new species. J. Crustacean Biol., 20, 132-152.

Taylor C.A., Schuster G.A., Cooper J.E., DiStephano R.J., Eversole A.G., Hamr P., Hobbs H.H. Jr., Robinson H.W., Skelton C.E. and Thoma R.F., 2007. A reassessment of the conservation status of crayfishes of the United States and Canada after 10+ years of increased awareness. Fisheries, 32, 372-389.

Todorov M., Antonova V., Hubenov Z., Ihtimanska M., Kenderov L., Trichkova T., Varadinova E. and Deltshev C. Distribution and actual status of stone crayfish populations Austropotamobius torrentium (Decapoda: Astacidae) in Natura 2000 protected areas in Bulgaria. Acta Zool. Bulg., in press.

Tricarico E., Vilizzi L., Gherardi F. and Copp G.H., 2010. Calibration of FI-ISK, an invasiveness screening tool for nonnative freshwater invertebrates. Risk Anal., 30, 285-292.

Trichkova T., Botev I., Hubenov Z., Kenderov L., Todorov M., Kozuharov D., Deltshev, C. and Füreder L., 2013. Freshwater crayfish (Decapoda: Astacidae) distribution and conservation in Bulgaria. Freshw. Crayfish, 19, 243-248.

Trontelj P., Machino Y. and Sket B., 2005. Phylogenetic and phylogeographic relationships in the crayfish genus Austropotamobius inferred from mitochondrial COI gene sequences. Mol. Phylogenet. Evol., 34, 212-226.

Trožić-Borovac S., 2011. Freshwater crayfish in Bosnia and Herzegovina: the first report on their distribution. Knowl. Managt. Aquat. Ecosyst., 401, 26.

Vlach P., Hulec L. and Fischer D., 2009. Recent distribution, population densities and ecological requirements of the stone crayfish (Austropotamobius torrentium) in the Czech Republic. Knowl. Managt. Aquat. Ecosyst., 394-395, 13.

Vrålstad T., Johnsen S.I., Fristad R.F., Edsman L. and Strand D., 2011. Potent infection reservoir of crayfish plague now permanently established in Norway. Dis. Aquat. Org., 97, 75-83.

Vrezec A., Jaklič M., Govedič M., 2013. Distribution patterns of indigenous and non-indigenous crayfish in Slovenia. In: Book of abstracts, Regional crayfish meeting CrayCro: 26th-28th September, 2013, Rovinj, Croatia, 31.

Weagle K.V. and Ozburn G.W., 1972. Observations on aspects of the life history of the crayfish, Orconectes virilis (Hagen), in northwest Ontario. Can. J. Zool., 50, 366-370.

Williams B.W., Proctor H.C. and Clayton T., 2011. Range extension of the Northern Crayfish, Orconectes virilis (Decapoda, Cambaridae), in the western Prairie Provinces of Canada. Crustaceana, 84, 451-460. 